\title{
ANTHROPOMORPHIC PEG-BASED SCULPTURES FROM THE BANDERAS VALLEY OF COASTAL WEST MEXICO
}

\author{
Joseph B. Mountjoy and José C. Beltrán \\ aDepartment of Anthropology, University of North Carolina, 1000 Spring Garden Street, Greensboro, NC 27412, USA \\ 'Centro Instituto Nacional de Antropología e Historia, Lerdo 76, and Museum Regional de Nayarit, Avenida México 91, Tepic, \\ Nayarit, Mexico
}

\begin{abstract}
Both the accidental as well as the purposeful discovery of a large number of anthropomorphic peg-based sculptures in the Banderas Valley in the states of Jalisco and Nayarit during the 1990s have provided a corpus of contextual and iconographic data that, along with conquest-period ethnographic data, allow for an assessment of the date and function of such figures. In addition, because of the similarity of these sculptural figures to ones of comparable dates in Central America, the case for significant preHispanic coastal contacts between the two areas is reinforced.
\end{abstract}

Interest in the interpretation of western Mexican stone sculptures began more than 100 years ago (Starr 1897), and the subject has been treated in detail recently by Eduardo Williams, who has written his doctoral thesis, a monograph, and four articles on the preHispanic sculptures of western Mexico (Williams 1988, 1991, 1992a, 1992b, 1992c, 1998). However, a major problem for Williams, or anyone else who has been interested in this subject, has been the lack of data on the archaeological context of the western Mexican stone sculptures, since almost all of them have been found by nonarchaeologists, are located in private collections or museums, and lack sufficient data on their provenience to establish their date or determine their function.

Unfortunately, some of these problems are associated with a large collection of stone sculptures that was discovered accidentally in 1991 by residents of the town of San Vicente in the Banderas Valley near the Pacific coast in southwestern Nayarit (Figure 1). This San Vicente collection is especially important because it consists primarily of large anthropomorphic sculptures of a type known as "peg-based" in Central America. Fortunately, however, a few similar sculptures have been found and carefully documented in nearby sites on the southern side of the Banderas Valley in northwestern Jalisco (Mountjoy 2000, 2004), allowing us to date such sculptures and consequently help us to understand how they may have functioned in the local pre-Hispanic society.

First, we will recount the discovery of the San Vicente sculptures, then describe and illustrate those of the anthropomorphic peg-based type and relate them to some described previously in the archaeological literature on western Mexico. Second, we will discuss the discovery of similar sculptures at nearby sites in Jalisco,

E-mail correspondence to:jbmountj@hotmail.com as well as describe those sculptures and illustrate four of them. Third, we will present data relevant to dating such sculptures and provide some ethnohistorical documentation that suggests how they may have functioned in local pre-Hispanic societies. We will close with a discussion of what these sculptures seem to indicate about long-distance coastal contacts.

\section{THE SAN VICENTE COLLECTION}

On the 11 May 1991, two men (Agustín Solis and Armando Paz) were excavating a septic pit for Mr. Solis's house in the town of San Vicente, Nayarit, on the northern side of the Banderas Valley, about $6.5 \mathrm{~km}$ from the Pacific coast, when they discovered a group of 18 anthropomorphic stone sculptures (Figures 2-3). According to the discoverers, the sculptures were found at a depth of $80 \mathrm{~cm}$ below the surface of the ground in an area of about $1 \mathrm{~m}^{2}$, and they had no apparent association with any other archaeological material (Regino and Ramírez 1991). A few days later, these men turned over 17 of the sculptures to an agent of the Federal Public Ministry, and a Puerto Vallarta newspaper, Vallarta Opina, published some photographs and a brief article about the find (Regino and Ramírez 1991). Three days later, another article was published about the sculptures by the same newspaper in which the recuperation of an eighteenth sculpture was reported (Alcaraz 1991).

Eventually, the 18 sculptures were taken to the Nayarit state museum, where several of them were placed on exhibit. In 2005, the sculptures were photographed at the Tepic museum by Joseph Mountjoy and Nathan Mountjoy, aided by José Beltrán. The sixteen anthropomorphic sculptures are described in detail, in descending order from the largest $(74.0 \mathrm{~cm}$ high) to the smallest (14.5 cm high), in Appendix A.

The two sculptures not included in Appendix A appear to be zoomorphic. One resembles the head of a pelican, and the other, 


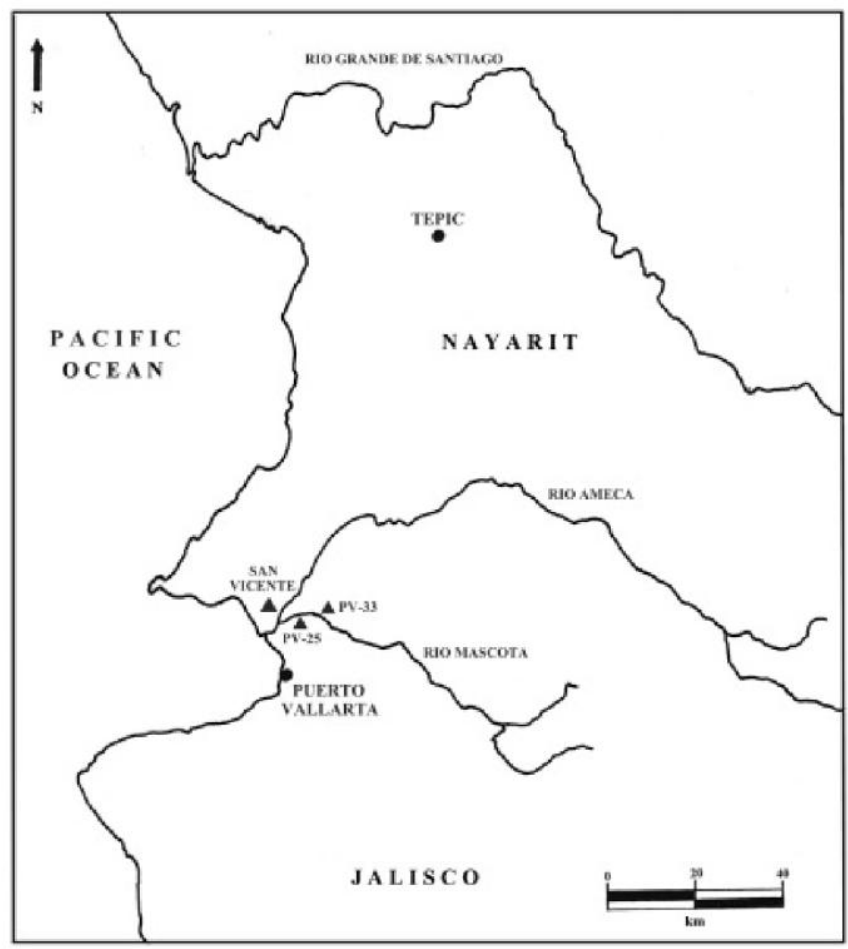

Figure 1. Map of the Banderas Valley area of Jalisco and Nayarit showing the three archaeological sites mentioned in the text where anthropomorphic peg-based sculptures have been discovered.

which is more abstract, has a head-like projection on the upper end with what could be construed to be the representation of a pelican-like mouth. Both of these are "peg-based."

The other 16 sculptures are anthropomorphic (Figures 4-19). No two of these sculptures are identical; all have individually distinctive features. Based on genitalia, ten are male, five are female, and one is indeterminate. However, some of the male

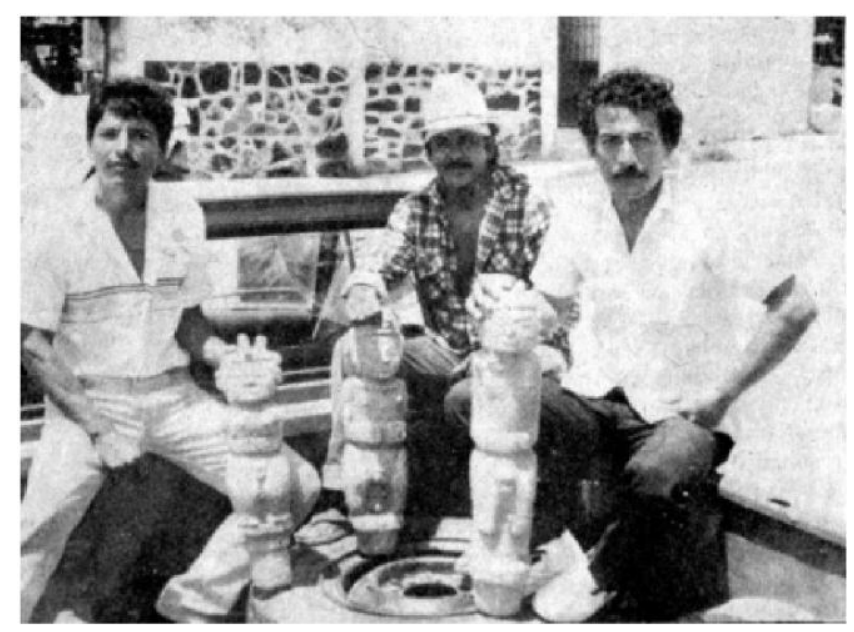

Figure 2. Vallarta Opina photograph of the discoverers of the San Vicente stone sculptures, along with three of the anthropomorphic peg-based figures from the collection.

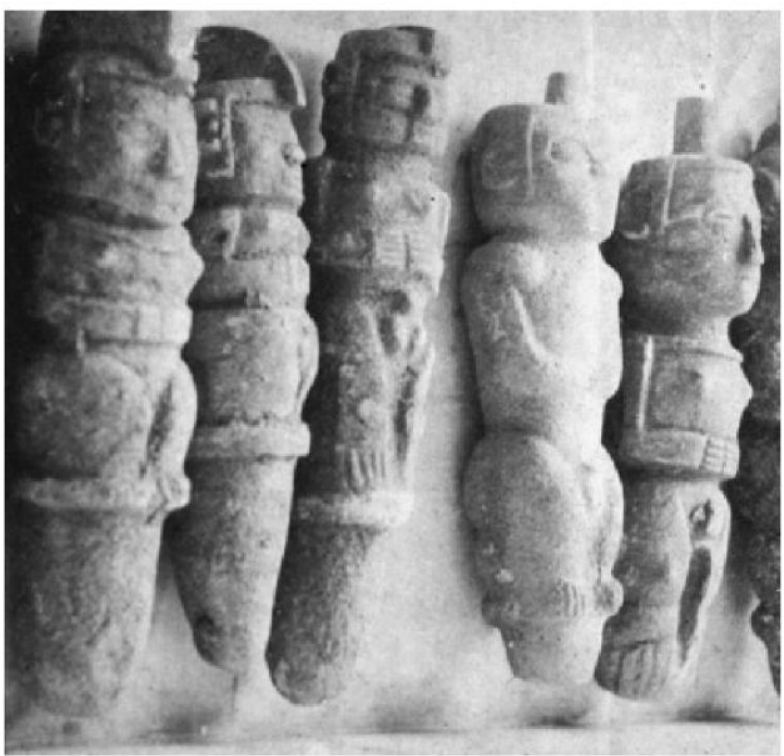

Figure 3. Vallarta Opina photograph of five of the San Vicente anthropomorphic peg-based stone figures.

sculptures have pronounced breasts that give them a somewhat hermaphroditic appearance.

Fourteen of the sculptures have a complete body, from head to feet, and 13 have a downward-projecting spike or peg that could have served to hold the sculpture upright in some sort of solid base that had a corresponding concavity. Most of the sculptures have the upper part of the arms vertically aligned to the sides of the torso and the lower part of the arms extended horizontally at a right angle so that the hands are placed close together on the stomach.

The most notable variation in the sculptures is found at the top of the head. Fourteen of the figures, both males and females, appear either to be wearing some sort of headgear, the sides of which fit over the ears, or to have their hair fixed into special tonsures. Some of these head adornments have a cylindrical projection on the top; others have one or two raised crests; and a few have both cylindrical and crest projections. It may be significant that the few figures with only a cylindrical projection on the top of the head are genitally male, as are the six tallest figures.

Most of the figures are in staid erect positions without any indication of activity or movement. However, the position of the legs and feet of one figure (Figure 16) suggests a walking movement, and one other figure (Figure 15) appears to be smoking a cigar.

It was hoped that the investigation of the San Vicente site would provide much needed precise information about the date and function of western Mexican sculptures. The Instituto Nacional de Antropología e Historia sent an investigative team headed by the archaeologist Gabriela Zepeda García Moreno to conduct excavations at the location of the find (Zepeda 1991). By the time Zepeda arrived, the deposit at the location of the discovery was no longer visible, and the excavation of six stratigraphic test pits in the immediately surrounding area produced no data that clarified the cultural, spatial or temporal context of the sculptures (Zepeda 1991). Zepeda speculated that the sculptures were either buried as a group to hide them, or as a ritual offering related to the gods or 


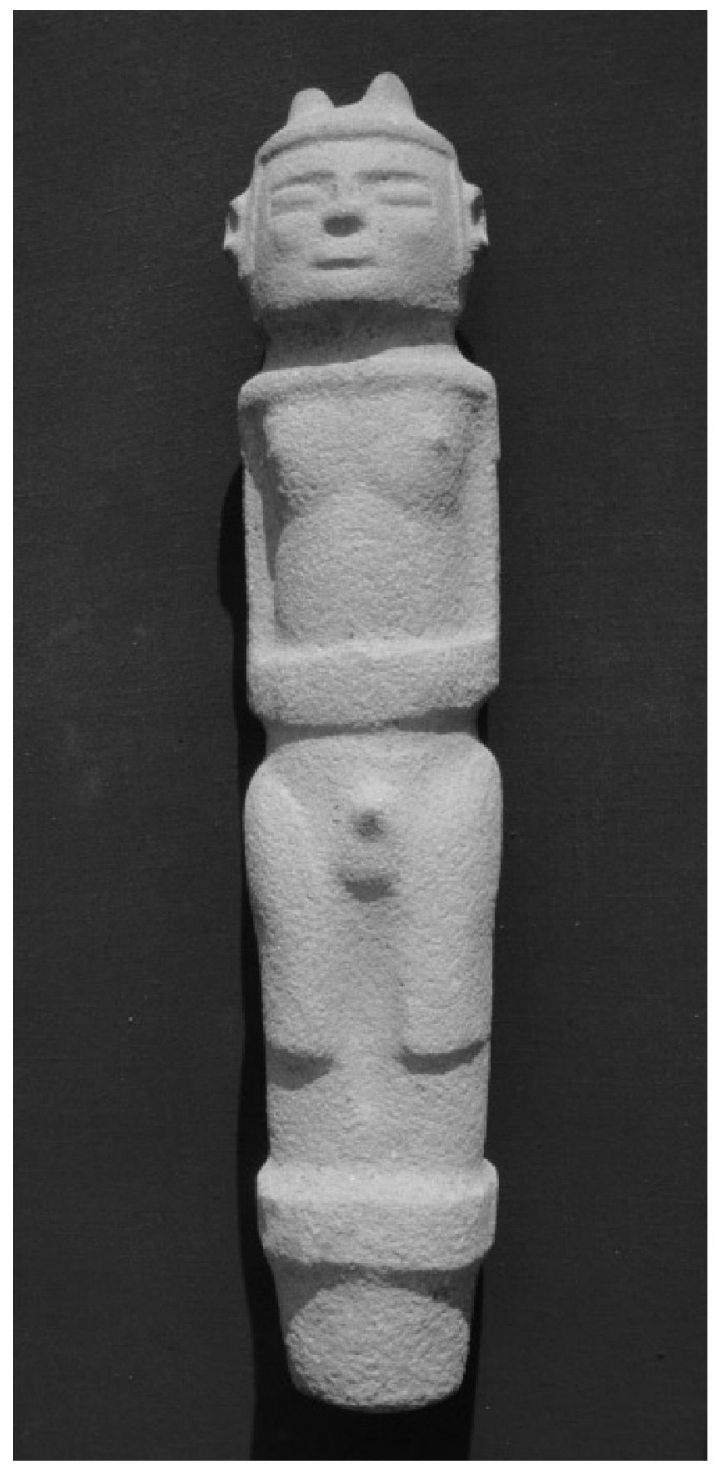

Figure 4. San Vicente anthropomorphic sculpture 1.

local authorities, and offered the opinion that they dated sometime within the middle to late Classic period (ca. A.D. 300-900), between the Shaft Tomb tradition and the Azttlán tradition (Zepeda 1991:19). Williams, however, tended to attribute the San Vicente Sculptures to the Aztatlán tradition (ca. A.D. 900-1200) (Williams 1998).

We, the authors, believe that data from our own excavations and surface studies in the Banderas valley clarify considerably the chronological placement and cultural function of the San Vicente sculptures, in some instances supporting the Zepeda (1991) and/or Williams (1998) interpretations, and in some instances not.

In 1996, Beltrán conducted a project of rescue archaeology at San Vicente in which he found surface evidence of an extensive pre-Hispanic occupation with several artificial mounds and abundant pottery sherds, none of which could be attributed to a period prior to the Late Postclassic (ca. A.D. 1300-1600; Beltrán 1996). Furthermore, Beltrán excavated the remains of a large urn in the town, one-and-one-half blocks away from the spot where the stone

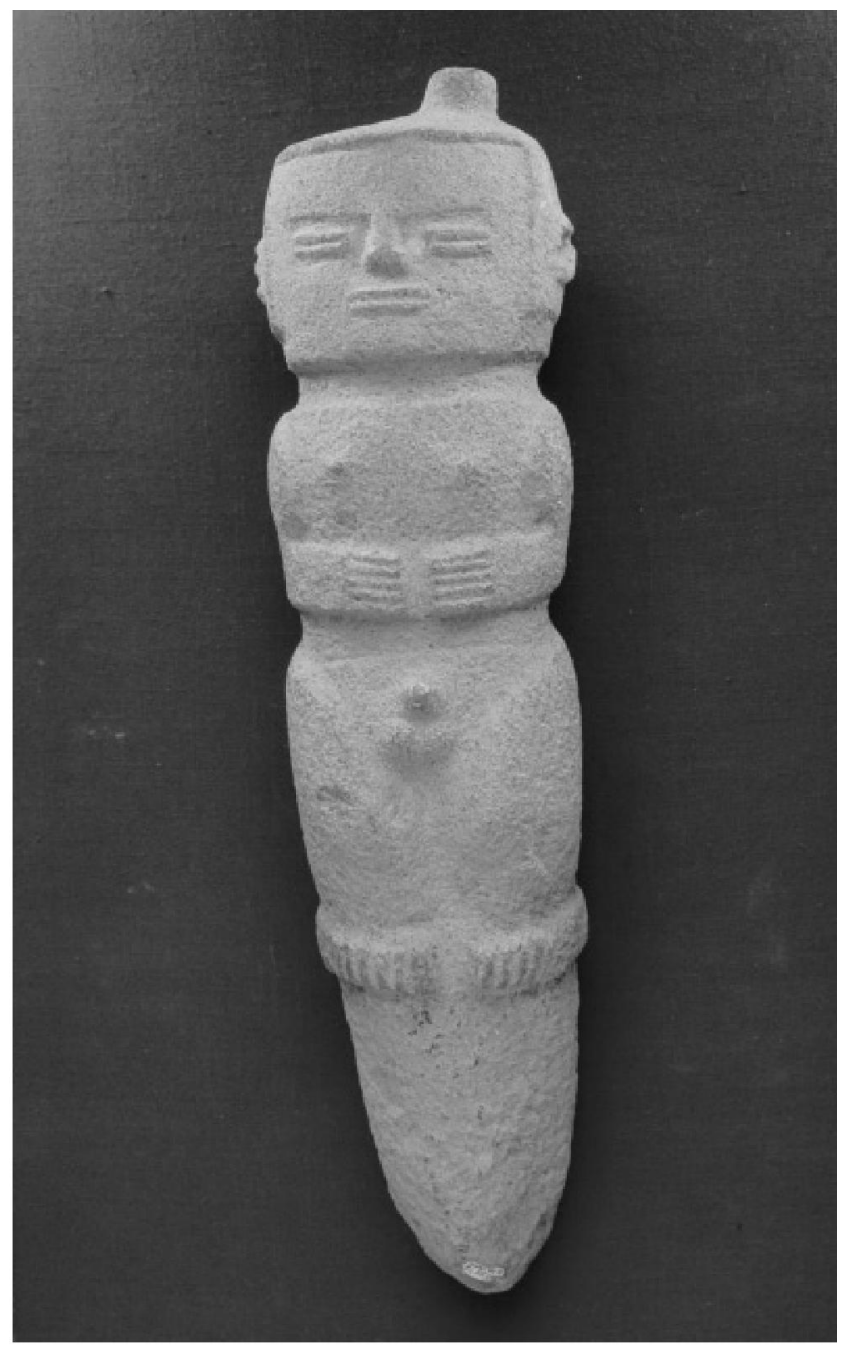

Figure 5. San Vicente anthropomorphic sculpture 2.

sculptures were discovered. Excavation revealed pre-Hispanic artifacts and pottery sherds exclusively attributable to the Late Postclassic period both inside the urn and in the soil around the urn extending from the surface to a depth of $65 \mathrm{~cm}$. Below this depth was sterile alluvium into which the base of the urn intruded. Two other large urns were reported to have been found during street construction some $15 \mathrm{~m}$ from the salvaged urn. Also, urns of similar size and shape (1.2 $\mathrm{m}$ and $1.4 \mathrm{~m}$ in diameter) were excavated by Beltrán in nearby Bucerias, Nayarit, on the coast, one of which contained-in addition to shells, stone artifacts, and Late Postclassic sherds-a copper fishhook (Beltrán 1996). Based on the evidence from Beltrán's investigations at San Vicente, there is no reason to attribute the stone sculptures found there to any preHispanic period other than the Late Postclassic.

Additional information on anthropomorphic peg-based sculptures includes two stone sculptures illustrated by Williams (1992a: Figures 73-74) that are virtually identical to the anthropomorphic sculptures found at San Vicente. There is no information on their original provenience. One is housed at the Museum of Compostela, Nayarit, and the other was photographed by Isabel Kelly during one of her field seasons. A third sculpture (Williams 1992a: 


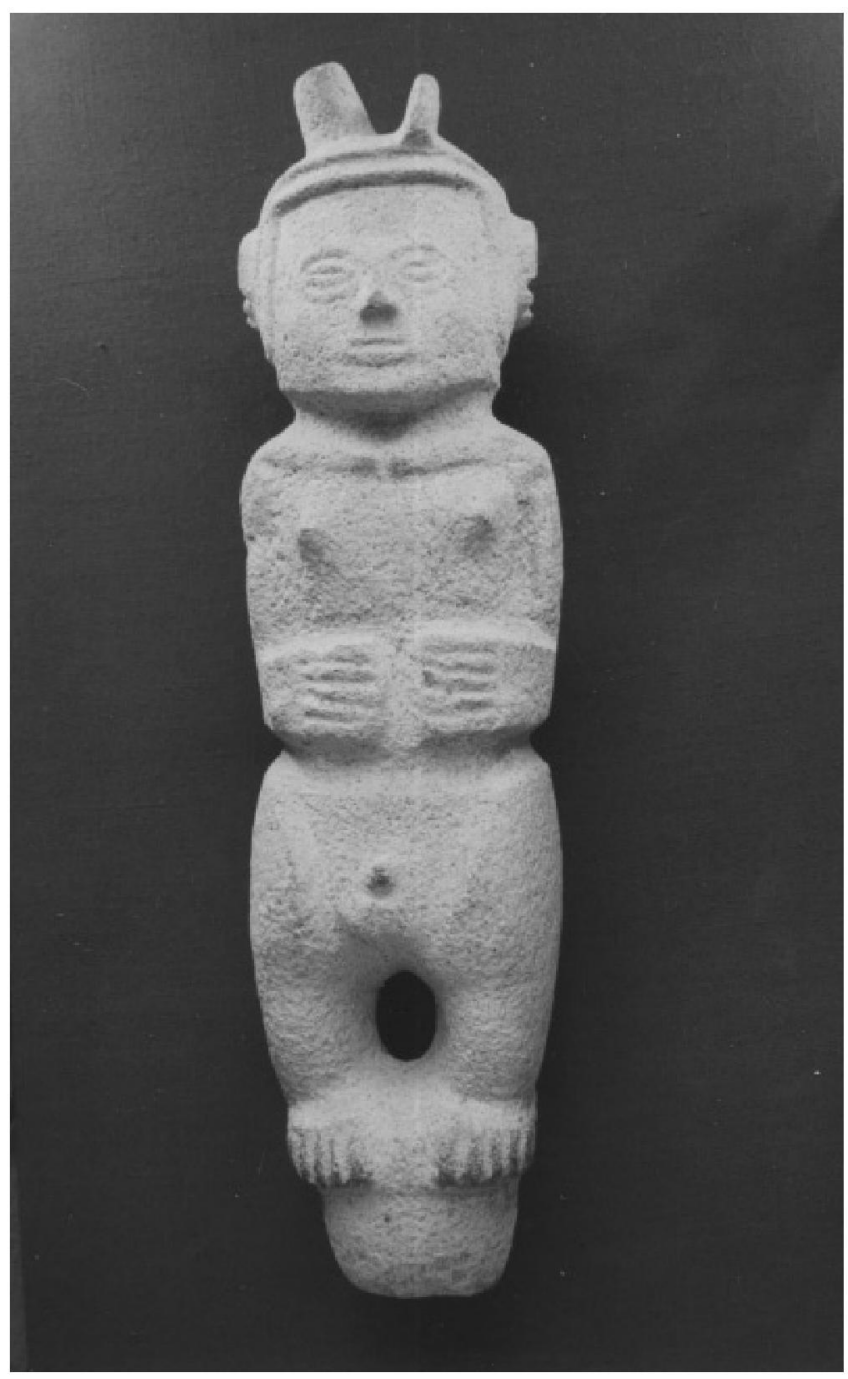

Figure 6. San Vicente anthropomorphic sculpture 3.

Figure 66) is similar to those from San Vicente. It is now on display at the Museum of Guadalajara and was reportedly found by a farmer at Teleacapan, Jalisco, on the southern side of the Ameca River about $40 \mathrm{~km}$ inland from Puerto Vallarta, after his horse stumbled over an oddly shaped stone while he was riding along a dirt road. Also, Williams (1992a: Figures 59-62) attributes at least eight other anthropomorphic peg-based sculptures to Jalisco, although they are of a much cruder style than those found at San Vicente, Nayarit.

\section{ANTHROPOMORPHIC PEG-BASED SCULPTURES FROMTHEMUNICIPALITY OFPUERTO VALLARTA}

Beginning in 1986 and continuing through 1994, archaeological investigations were conducted by Mountjoy in the municipality of Puerto Vallarta on the southern side of the Banderas Valley. These investigations focused on the site of Ixtapa, the largest site in the municipality of Puerto Vallarta, Jalisco (Mountjoy 1992, 2002), but other pre-Hispanic sites in the immediate vicinity were recorded and studied, as well. In 1990, the lower half of an anthro-

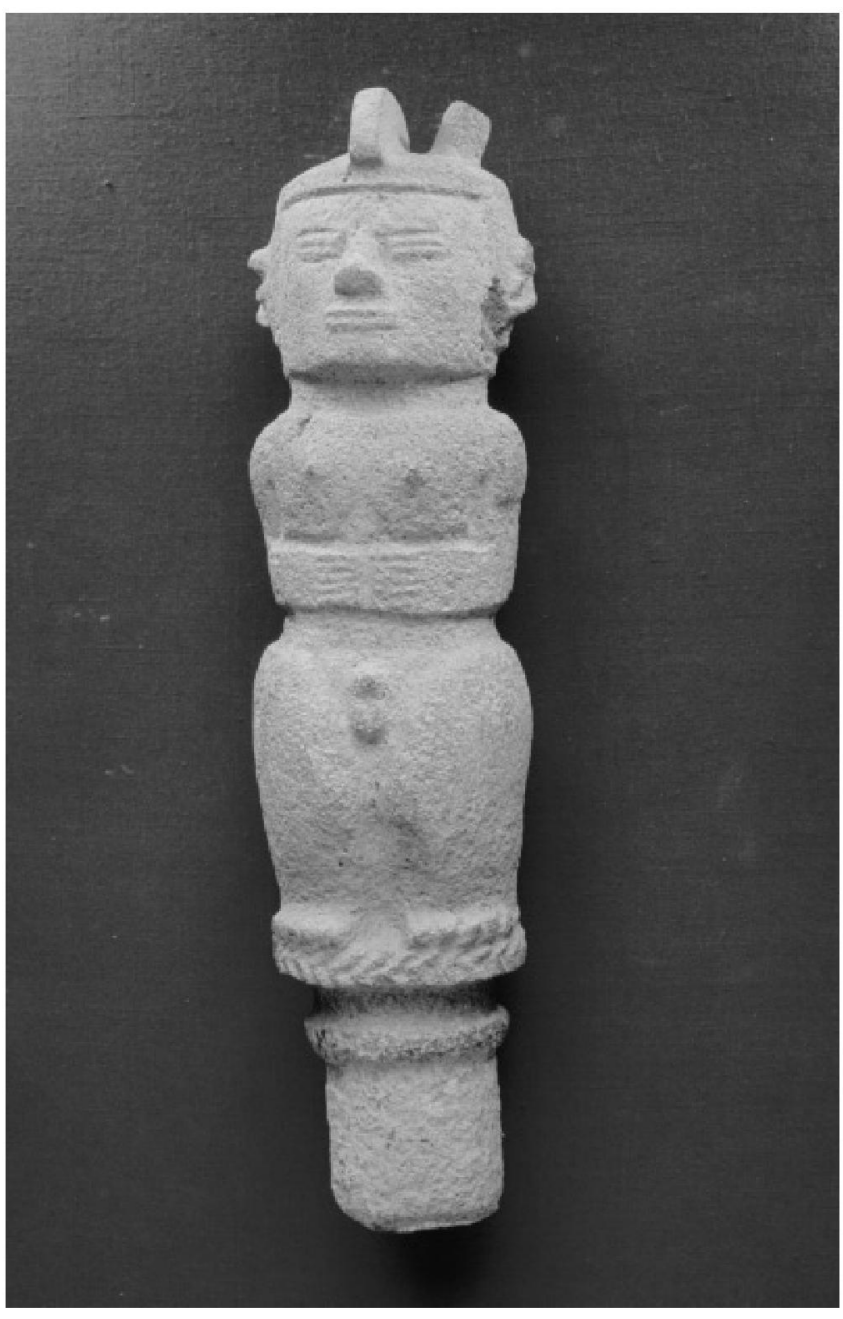

Figure 7. San Vicente anthropomorphic sculpture 4.

pomorphic peg-based stone sculpture (Figure 20) was found on the surface of the El Llanito del Tanque (PV-25) site in the foothills south of Ixtapa (Figure 1).

The sculpture is missing the head. From the neck to the lowest point, the piece measures $25 \mathrm{~cm}$, and the body has the form of a cylinder $11 \mathrm{~cm}$ in diameter. The arms are bent at the elbows, with the hands resting on the stomach, and the legs join below the knees. The sculpture has masculine genitals, as well as pronounced breasts, and below the legs the peg base appears to be carved to resemble a penis. This sculpture was found adjacent to a rectangular structure with stone foundations and a floor of burned clay. The artifacts found during the subsequent excavation of this structure pertain to the local El Llanitos phase (ca. A.D. 6001100). However, the structure was found to have been cut diagonally by another structure, associated with which we recovered two prismatic obsidian blades and pottery sherds that probably date this second foundation to the Early Postclassic (Aztatlan) phase (ca. A.D. 1100-1300). Unfortunately, because of the different dates of the excavated remains and the fact that the sculpture was found on the surface, neither the precise chronological placement nor the function of the stone sculpture could be determined. 


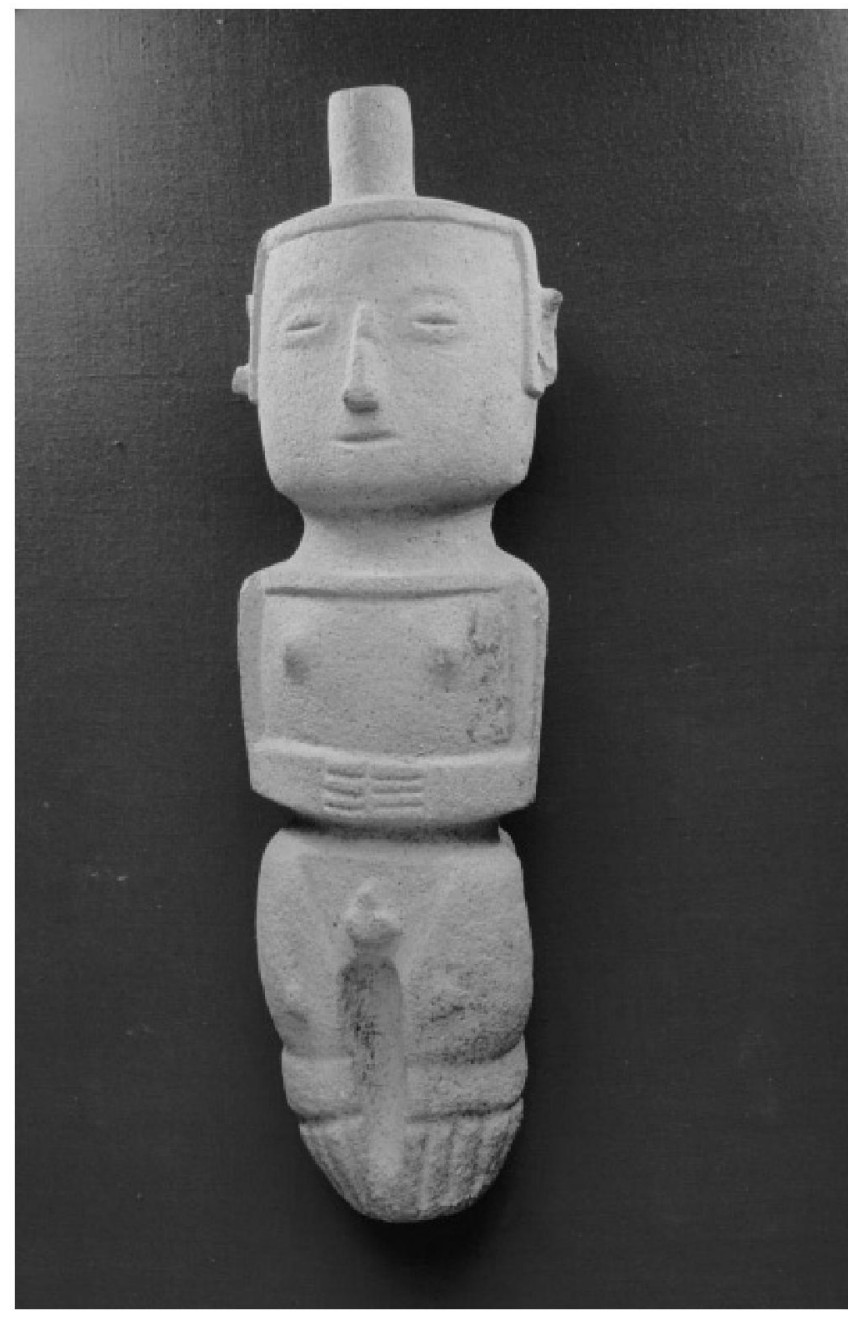

Figure 8. San Vicente anthropomorphic sculpture 5.

However, considerably more definitive information on additional stone sculptures was obtained in 1992 and 1993 at the nearby PV-33 (El Ranchito) site in the municipality of Puerto Vallarta (Figure 1; Mountjoy 2002, 2004). During the study of the site, townspeople described a sculpture almost a meter tall that was uncovered during the construction of the town's bullfighting ring. Another sculpture was said to have been found when the townspeople dug a trench for a water line. Another was reportedly found when a pit was excavated for one of the supports for the foundations of a house. Another was said to have been uncovered by rainfall in the patio of a house. A further sculpture was reportedly found in the patio of another house. And a sculpture in the form of a rabbit apparently was found by a woman when she was sweeping the patio in front of her house. Unfortunately, none of these sculptures remained in the town as of 1992.

Nevertheless, one man, Isidro Luna, had saved parts of two stone sculptures that his mother had found at the foot of a tree that his father had planted in 1970 at the entrance to the patio in front of his house. One of the fragments consisted of the upper half (the head to below the breasts) of an anthropomorphic sculpture possibly of granite, measuring $15 \mathrm{~cm}$ in height, $12.5 \mathrm{~cm}$ in width, and $7.5 \mathrm{~cm}$ in thickness (Figure 21). It is quite similar to one of the

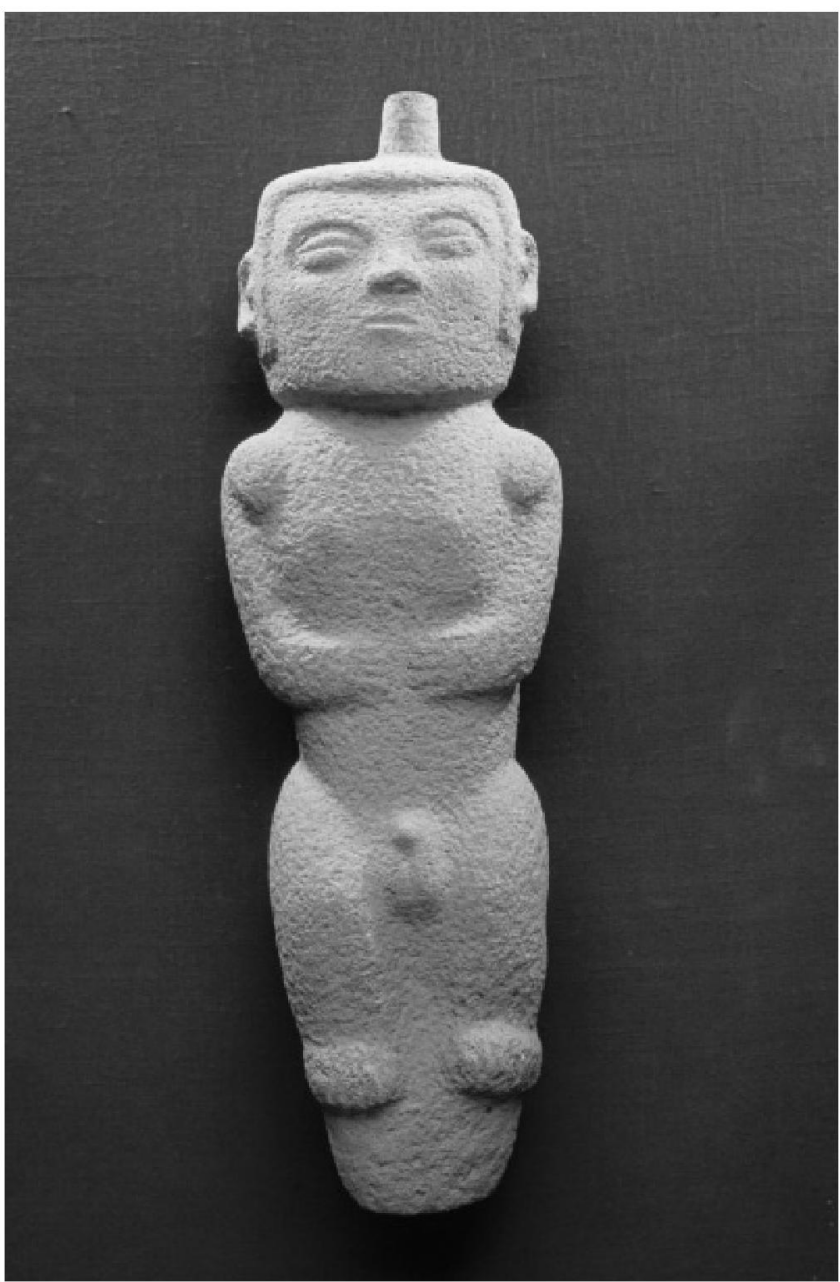

Figure 9. San Vicente anthropomorphic sculpture 6.

sculptures found at San Vicente (Figure 14). The other fragment was the right hand, part of the lower arm, and part of the torso of a very large sculpture, with the hand turned downward like one of the San Vicente sculptures. The hand alone measured $7 \mathrm{~cm}$ wide, not much smaller than an actual human hand.

Excavating in the area at the base of the tree in 1992, we removed the contents of a pit that measured $185 \mathrm{~cm}$ north-south by $105 \mathrm{~cm}$ east-west. What was left of the pit reached a depth of $35 \mathrm{~cm}$ below the surface, and the pit was full of rocks, many of them burned and/or fractured, plus some grinding stones, one prismatic obsidian blade, one obsidian flake, and 109 pottery sherds. In addition to these artifacts, we found at least six fragments of stone sculpture. It was possible to fit some of them together and reconstruct a large part of a head with face and headgear or tonsure, as well as another piece with hands, arms, and stomach that was probably part of the body that corresponded to the head (Figure 22). This sculpture is of the same style as those found at San Vicente. The head measured $16 \mathrm{~cm}$ wide and $13.5 \mathrm{~cm}$ high and was probably about the same size as the largest of the San Vicente anthropomorphic sculptures. We also pieced together what seems to be a portion of the body of another sculpture and what was possibly the peg base of a third sculpture, of granite. 


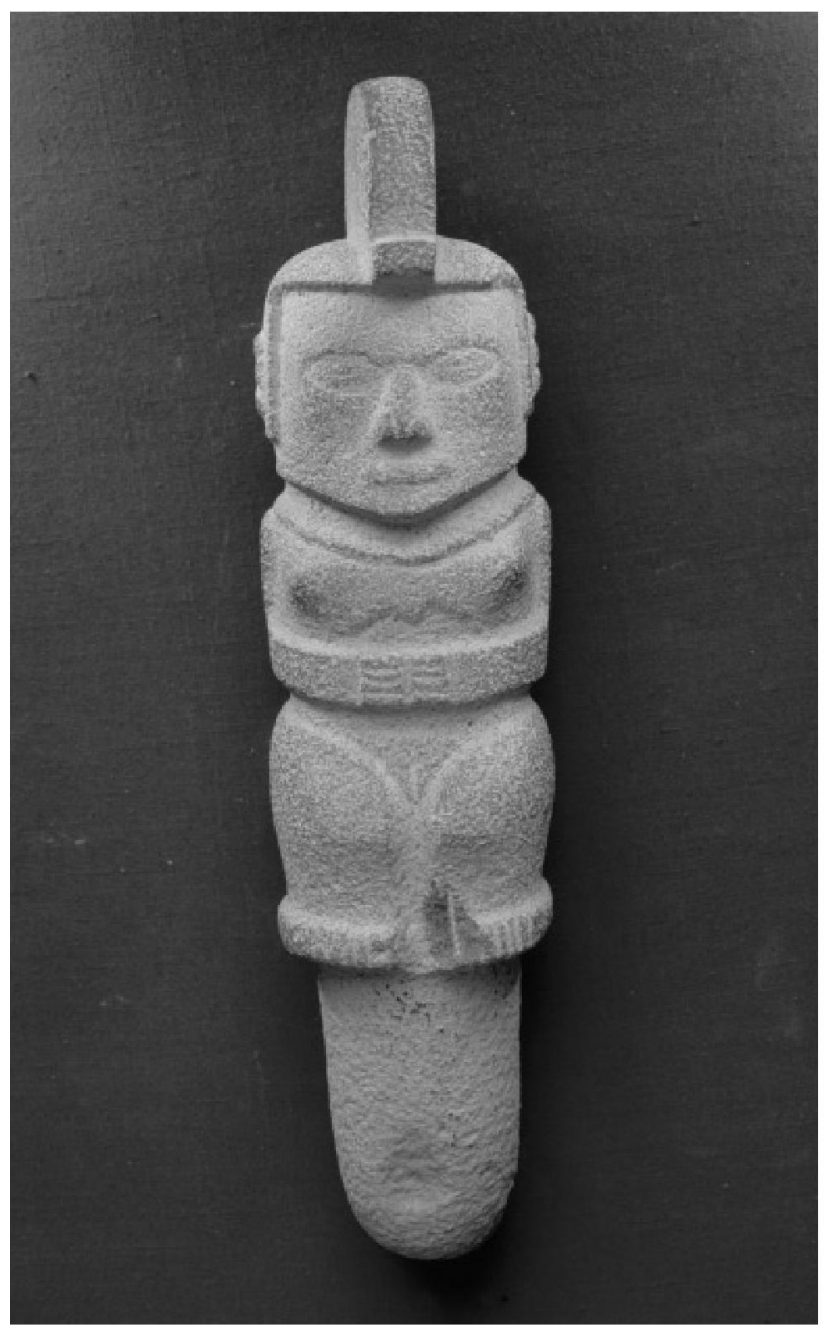

Figure 10. San Vicente anthropomorphic sculpture 7.

At least two of these El Ranchito sculptures are of a vesicular basalt-like volcanic stone that contains small olivine crystals, and this kind of stone appears to be uncommon, if present at all, in the Banderas Valley. It is different from the vesicular basalt or granite of the San Vicente sculptures. Two of the sculptures had remains of red pigment adhering to the surface. Various fragments of both sculptures showed evidence of fissures and breakages, some of which appear to have been produced by contact with fire. The surface of some of these sculptural fragments had been exposed to a fire of such high temperature that areas of their surface had become vitrified, in contrast to the nonsculptural stones in the pit.

All of the sherds of decorated pottery that could be attributed to a pre-Hispanic phase were of the Banderas (Late Postclassic) phase (ca. A.D. 1300-1600; Mountjoy 2002, 2004). The sides of the pit appeared to have been burned, and we found a large amount of firewood carbon at the bottom of the pit. A sample of this carbon gave a radiocarbon date of A.D. $1550 \pm 60$ radiocarbon years (Beta-62397) calibrated to A.D. 1435-1660 at 95\% confidence, with calibration intersections at A.D. 1510, 1595, and 1615. Therefore, the San Vicente-style anthropomorphic peg-based stone sculptures appear to have been in use during the Late Postclassic (local Banderas phase), perhaps until the local indigenous popu-

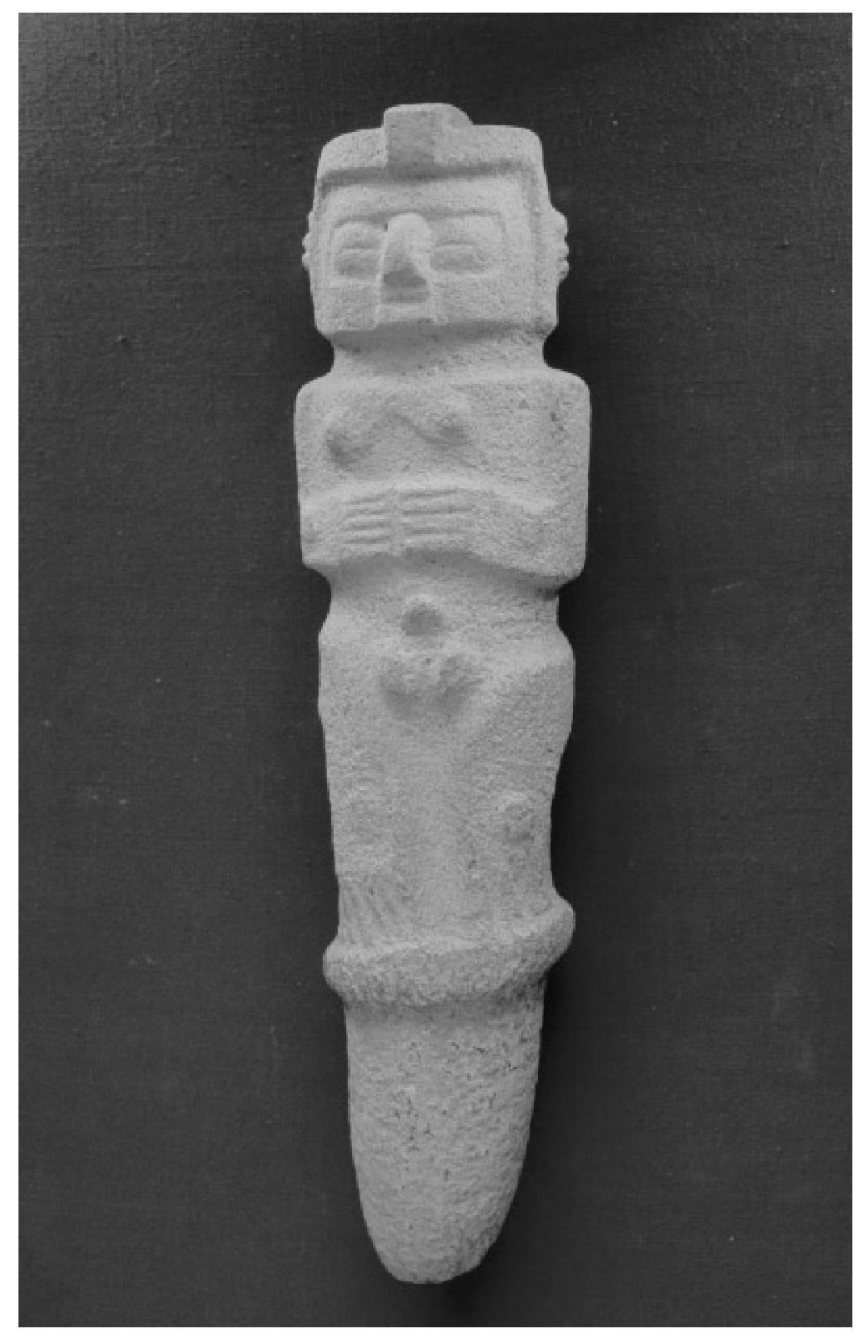

Figure 11. San Vicente anthropomorphic sculpture 8.

lation dwindled away to virtually nothing about 1620 , although we cannot definitively rule out an introduction of such sculptures into the Banderas valley area as early as the local Aztatlán phase (ca. A.D. 1100-1300).

It seems quite possible that the pieces of sculpture that were found burned and broken in the pit at El Ranchito represent the act of destruction of indigenous "idols" by the Spanish. There is an account of the visit by a Spanish friar, Francisco de Lorenzo in 1530 to the area of El Tuito, the indigenous province in northwestern coastal Jalisco immediately to the south of the Banderas Valley, where he found that the natives worshipped many idols. After Fray Francisco de Lorenzo had convinced the natives of the error of their idol-worshipping ways, the natives

brought all their idols and placed them at the feet of the blessed Father, and he reduced to dust those idols that were of clay, and those that were combustible he cast upon the flames. (Mariano de Torres 1965:58-59; translation by Mountjoy).

However, it is also possible that the sculptural remains in the El Ranchito pit represent the post-destruction inclusion of burned and broken "idols" as part of the stones used in a pit oven like 


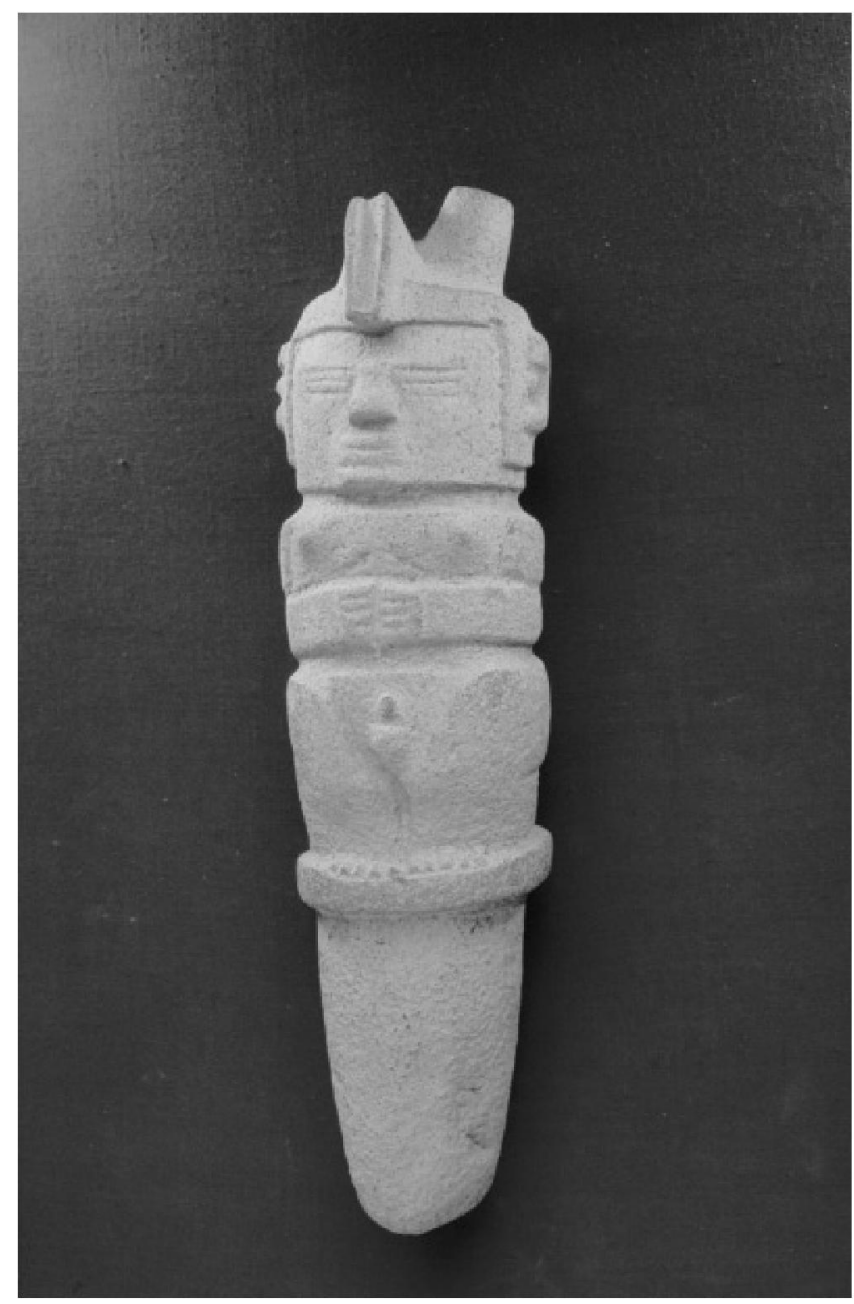

Figure 12. San Vicente anthropomorphic sculpture 9.

those known to have been used into colonial times to roast hearts of the maguey plant.

In 1993, in another part of the El Ranchito site (Figure 1), some $120 \mathrm{~m}$ southwest of the pit that yielded these pieces of sculpture, the torso of a female (Figure 23), apparently in the San Vicente style, was discovered lying next to the house where the woman was reported to have found the stone sculpture of a rabbit while sweeping her patio. This sculpture was carved of volcanic stone, and the fragment measured $13.5 \mathrm{~cm}$ high and $8.6 \mathrm{~cm}$ wide. In an area near where the sculpture was found we excavated $25 \%$ of the interior of a square house foundation. Eighty percent of the decorated pottery that was found on the floor of the house was attributable to the Banderas (Late Postclassic) phase (A.D. 13001600; Mountjoy 2002, 2004). We also excavated a trench northeast of the Late Postclassic house, finding in the process a small fragment $(7.5 \mathrm{~cm} \mathrm{X} 4.5 \mathrm{~cm})$ of a sculpture of granite, likely a part of the ring that is found on the San Vicente figurines often formed by the feet just above the peg base. The pottery sherds found associated with the sculptural fragment were of the same Banderasphase types found in association with the house floor.

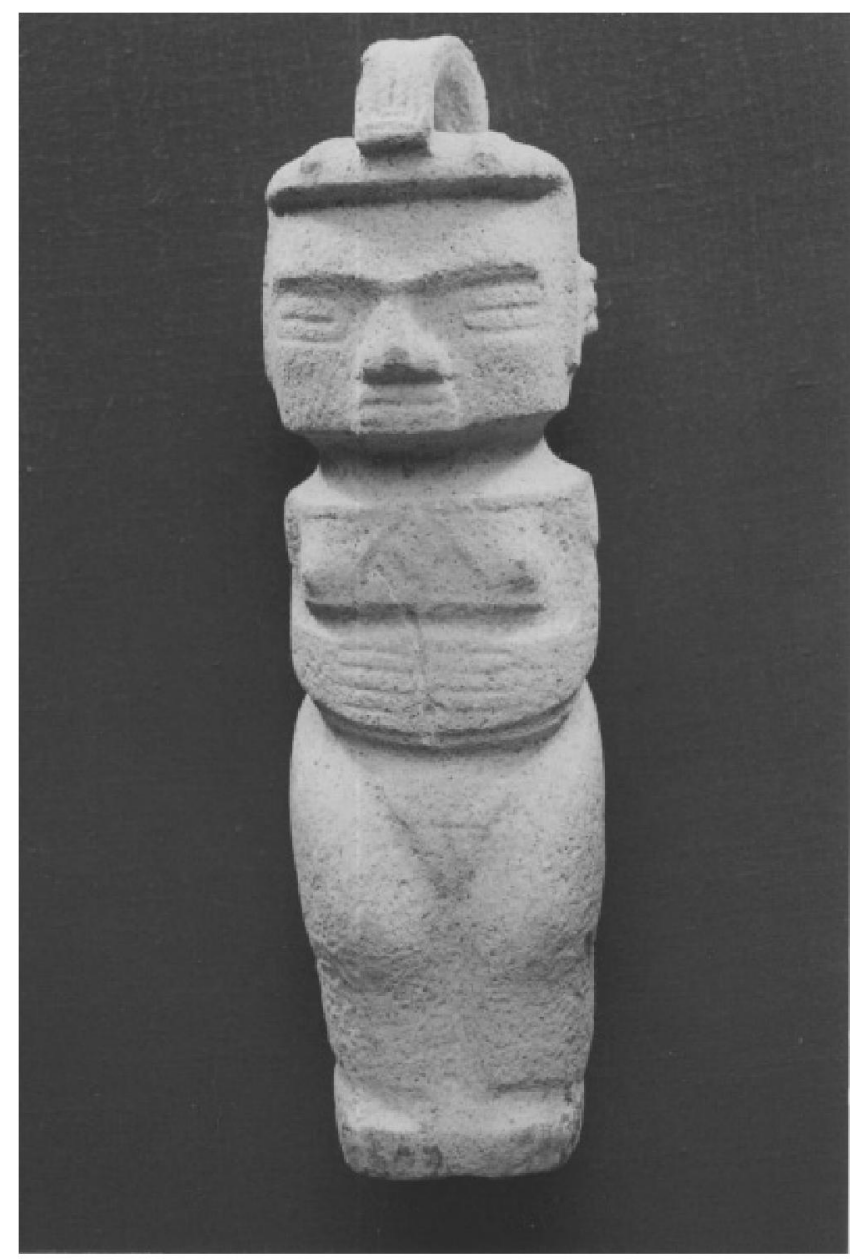

Figure 13. San Vicente anthropomorphic sculpture 10.

\section{THE FUNCTION OF THE SCULPTURES}

Because these anthropomorphic peg-based sculptures appear to have been in use during the Late Postclassic period in the Banderas Valley, it should therefore be possible to use ethnohistorical data from indigenous culture in the coastal area of Jalisco to get ideas about their possible function. Ethnohistorical data have been used by Williams (1988, 1991, 1992a, 1992b, 1992c, 1998) to interpret other types of western Mexican stone sculptures, but there is one ethnographic source from the coast of Jalisco that is not cited by Williams and that seems especially useful for interpreting the anthropomorphic peg-base sculptures from the Banderas valley: the Relación Geográfica de la Villa de la Purificación compiled in 1585 by René Acuña (1988).

This Relación includes information about towns in the central part of the coast and the western highlands of what is now the state of Jalisco. The document mentions the use of stone idols by indigenous peoples in the settlements of Opono, Cocochol, Tlaltenpa, Ocotitlan, and Melagua. In many cases, the indigenous people left offerings to these idols, including deer meat, honey, beads, 


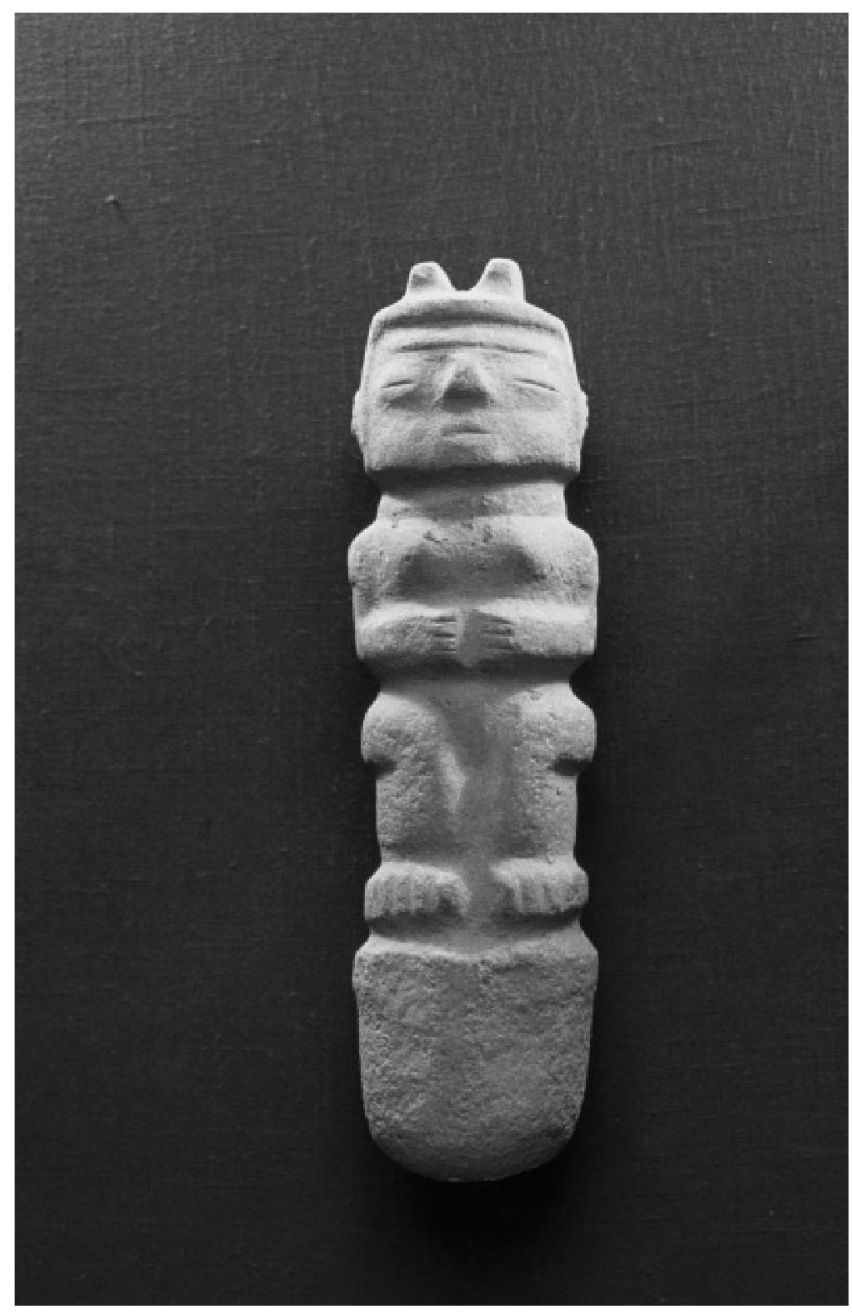

Figure 14. San Vicente anthropomorphic sculpture 11.

bows and arrows. In one case, they left the hearts of enemies that they had killed in battle. It is probable that many of these idols were anthropomorphic in form, and information from Tlaltenpa and Ocotitlan is very specific with respect to this:

Their rites of adoration, which were dedicated to the devil, took place on the top of a very high hill where they had a house constructed for the idol which was of stone and carved in the form of a person and to which they gave offerings of beads and bowls and arrows, and to whom they spoke in order to receive advice concerning warfare [Acuña 1988:223; translation by Mountjoy]

Idols appear commonly to have served an oracular purpose in the indigenous societies of northwestern Mexico, especially among the Tepehuanes in the area of western Durango (Pérez de Ribas 1944:166, 186). Two other accounts of "idols" found among the Tepehuanes during the process of initial missionization seem particularly relevant to the discussion of the function and destruction of anthropomorphic peg-based stone figures from the Banderas Valley area of Jalisco and Nayarit.

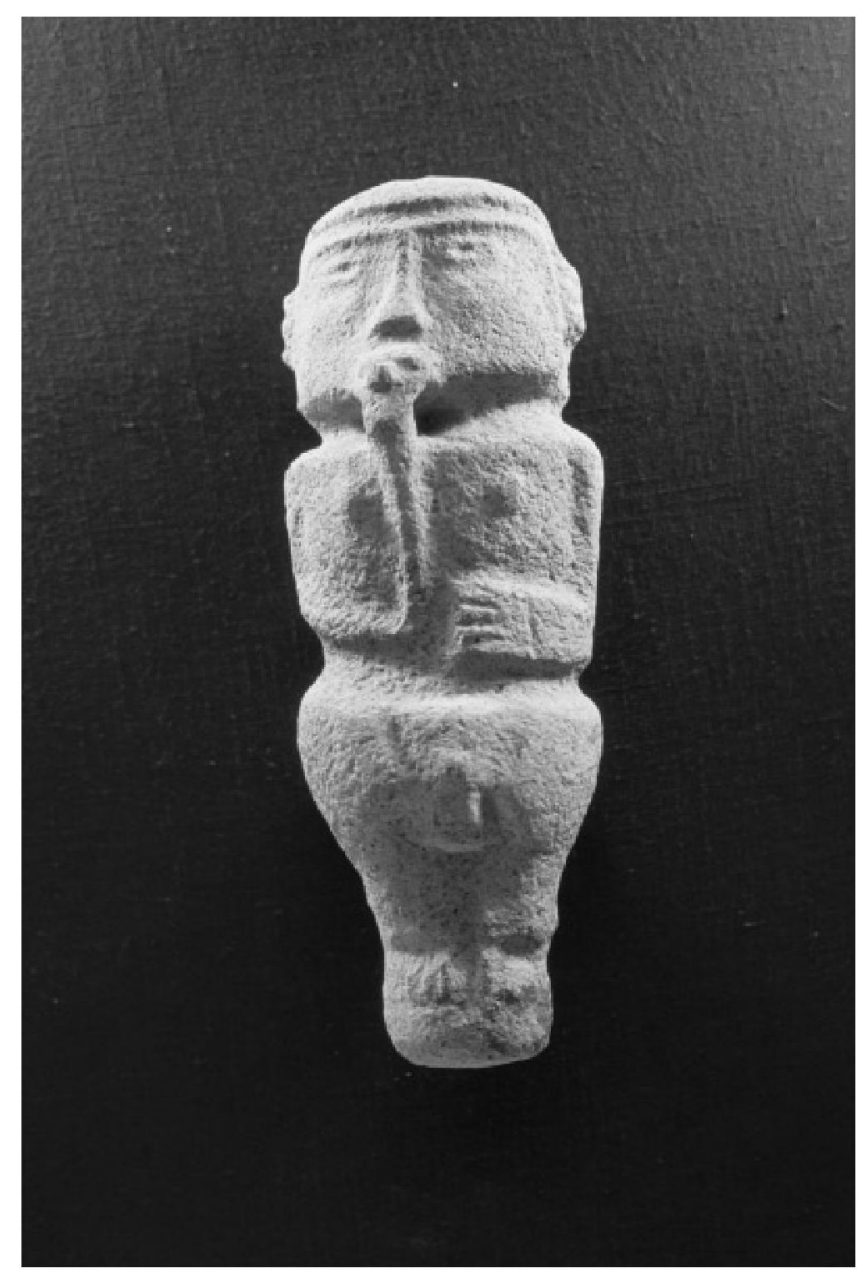

Figure 15. San Vicente anthropomorphic sculpture 12.

The first of these accounts, dated to 1579 , stems from the mission efforts of Father Jerónimo Ramírez in the Tepehuan area around the major settlement of Papazquaro, Durango, about 140 $\mathrm{km}$ northwest of present-day Durango, which at that time was known as Guadiana. One of the natives living in a small outlying settlement visited by Father Ramírez had in his possession a naturally shaped stone, roundish and somewhat bigger than an apple. Although reluctant, the man finally brought the "little idol" to Father Ramírez, wrapped up so that the other natives would not be forced to gaze upon it, since to do so might cause them to drop dead on the spot. The man told Father Ramírez that the stone had rolled to him and spoken to him, telling him it had the power to cure and cause illness and that it contained a power that it could transmit to a warrior when he carried it into battle. After the stone had been in his possession for a while, the man discovered that it could also foretell things, such as the outbreak of warfare. The following day, Father Ramírez requested that

a Spaniard bring an anvil of iron, and with blows from a large mining hammer of stone [the little idol] became powder, and the powder was immediately cast into a fire that the local na- 


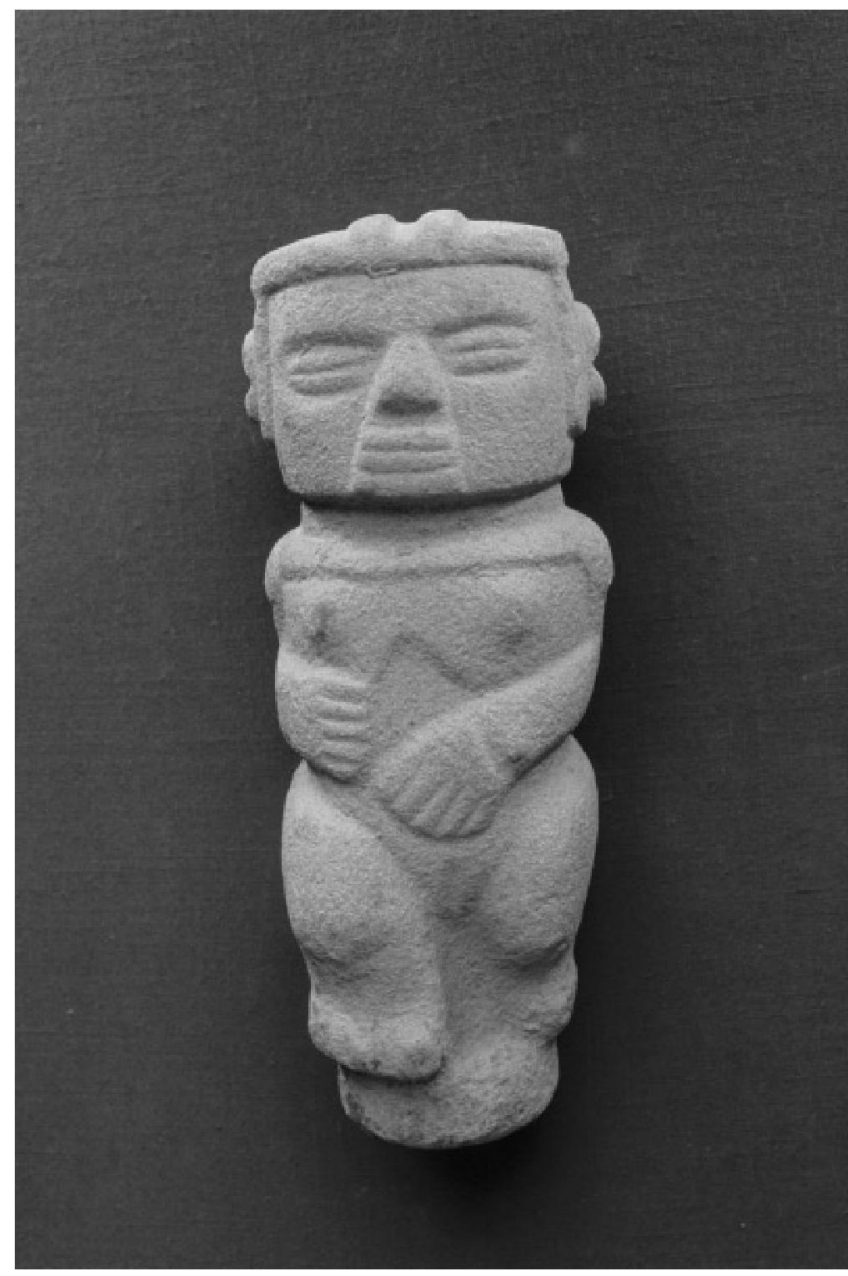

Figure 16. San Vicente anthropomorphic sculpture 13.

tives had prepared [Pérez de Ribas 1944:146-147; translation by Mountjoy].

Another highly revered "idol' that seems to have been sculptured into an anthropomorphic peg-based form similar to the sculptures found at San Vicente, Nayarit, was discovered by one of the fathers who was sent by Captain Mateo de Vezga, the governor of New Vizcaya (1620-1625), to continue missionizing Tepehuanes near Papazquaro, Durango. The father found that the "idol' had been placed on the top of a "little hill' (artificial mound?) at their settlement. According to the father, it was made

of stone, five palms in height [ca. $55 \mathrm{~cm}$ ], with the head of a man and the remaining part in the form of a column. Next to it were many offerings of arrows, animal bones, ollas, herbs, tree branches and beads of the kind they use for jewelry. Another idol of stone in the form of a spiral shell was placed next to it [Pérez de Ribas 1944:153; translation by Mountjoy].

After the father had converted the natives to Christianity, he took the converts to the place where the "idol' stood. There the native chief attacked the stone, hurling it down the slope, where it

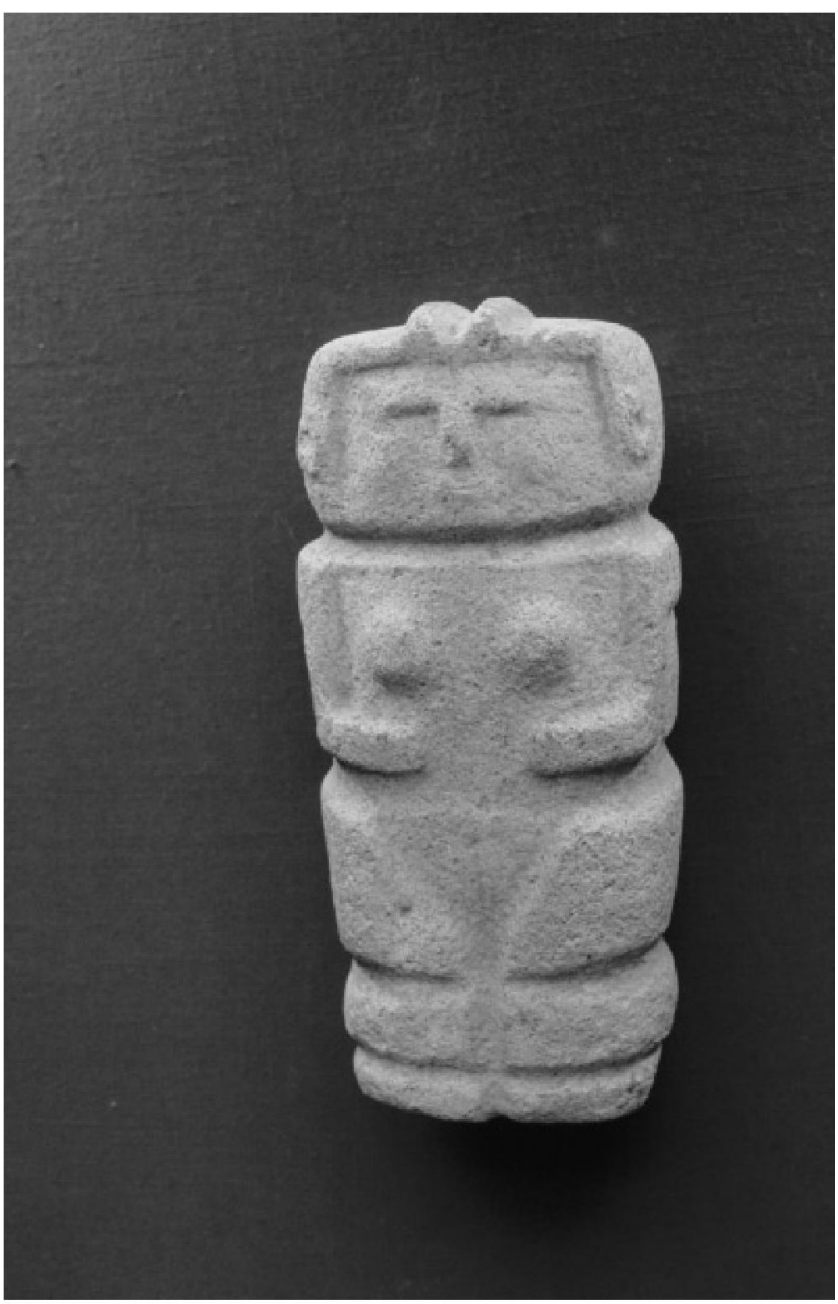

Figure 17. San Vicente anthropomorphic sculpture 14.

eventually came to rest on the bottom of the river located at the base of the hill. Afterward, the natives built a large cross that they decorated with flowers and placed on the spot where the idol had stood (Pérez de Ribas 1944:153-154).

If the anthropomorphic peg-based sculptures of the San Vicente style were "idols' that the indigenous peoples used in the fashion suggested by these ethnohistorical accounts, they would have functioned as divine oracles either for an individual shamanistic leaders or for the entire population of a settlement, and the detailed, anatomically realistic representation of the ears of most San Vicente figures might be a reflection of this.

However, some of the characteristics of the San Vicente-style anthropomorphic sculptures suggest a general association with fertility, an association clearly not at odds with oracular prognostications. One of these characteristics is the clear sexual-and in some cases, somewhat hermaphroditic-characteristics of the sculpture, as well as the phallic form of one or more of the peg bases, and perhaps even the cylindrical and crest representations on the top of the head. Some of the sculptures may have been stuck upright into the ground as fertility symbols, reminiscent of the use of phallic-shaped wooden digging implements in the Xochimilco area of the Valley of Mexico by the contemporary Mexica or 


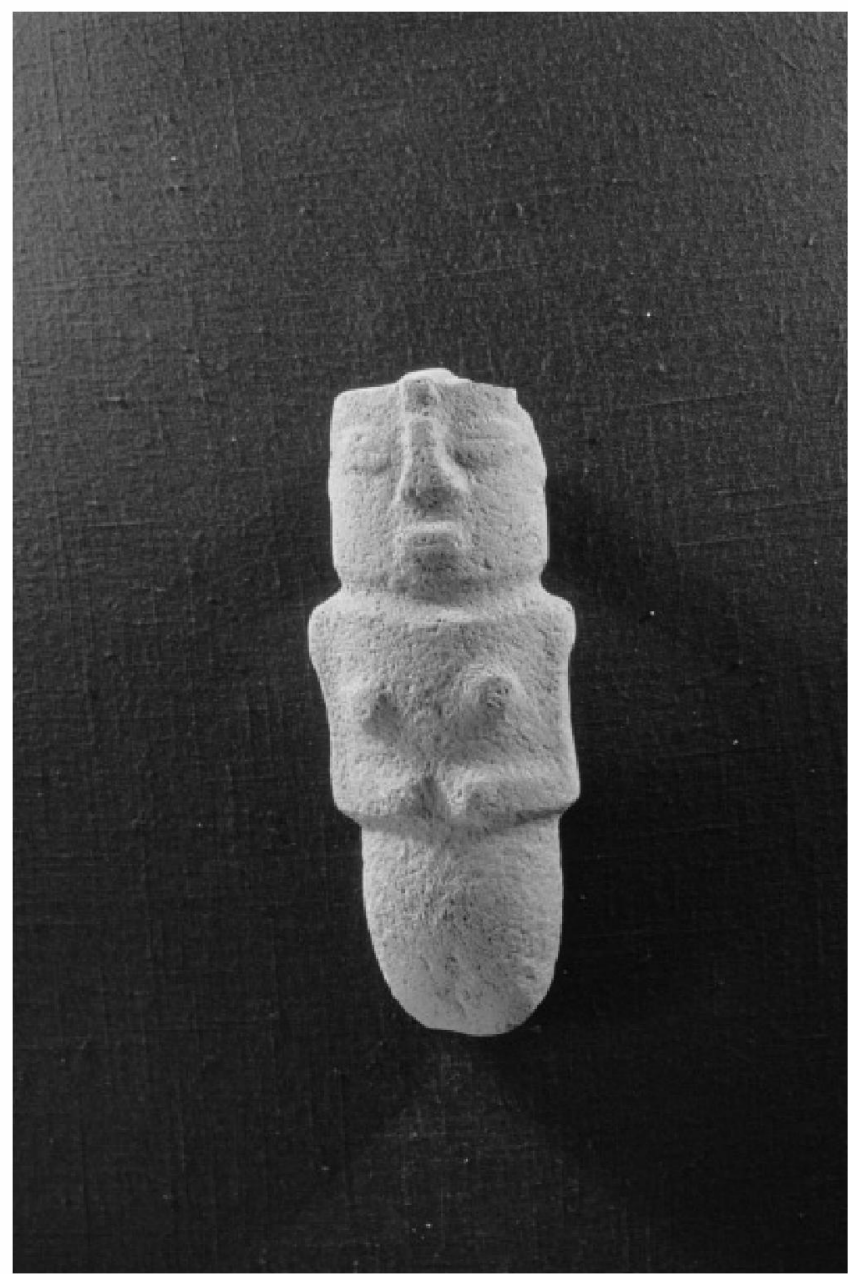

Figure 18. San Vicente anthropomorphic sculpture 15.

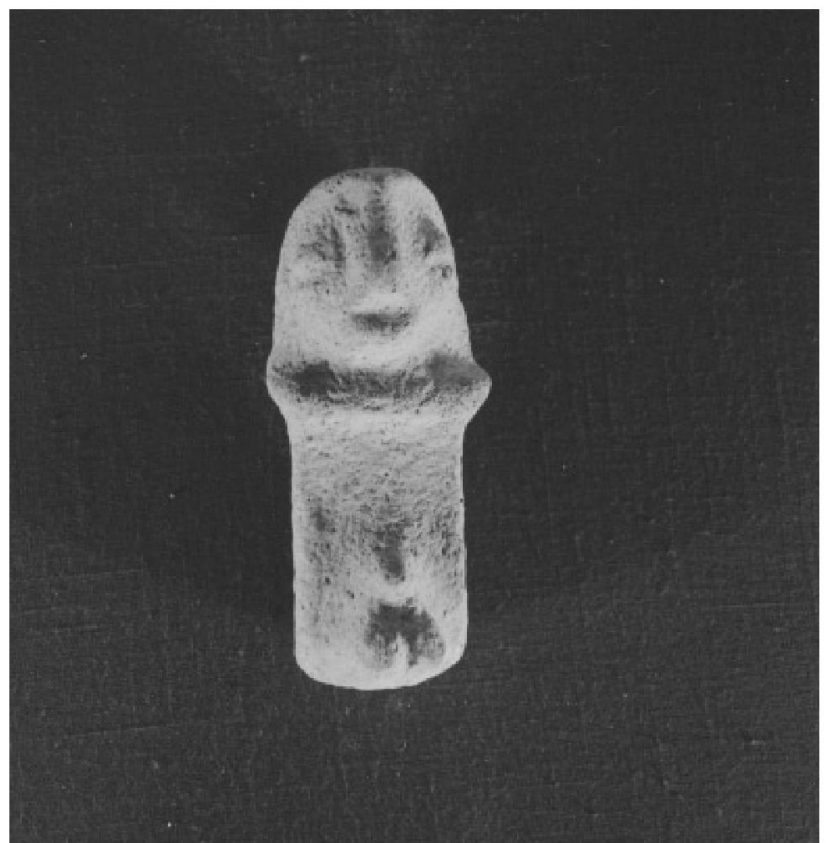

Figure 19. San Vicente anthropomorphic sculpture 16.

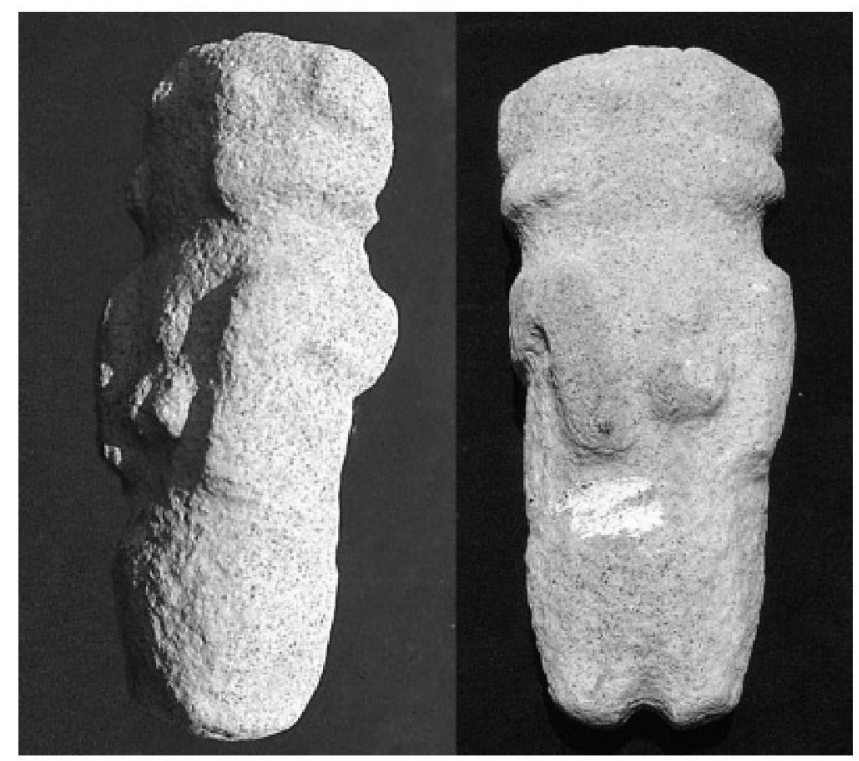

Figure 20. Two views of the lower half of an anthropomorphic sculpture from the El Llanito del Tanque (PV-25) site, Jalisco.

Mexica-related people who used the implements to "impregnate" the earth with seeds at planting time.

The fact that the San Vicente sculptures were buried as a group in relatively flat, low-lying land on the up-slope edge of the Ameca River floodplain, within a major Late Postclassic (Banderasphase) settlement on the northern side of the Banderas Valley, and without any apparent association with ritual structures, could indicate that they were buried there to hide them from the Spanish friars. This way, they would have been protected from the kind of Spanish missionizing destruction that was befalling stone "idols"

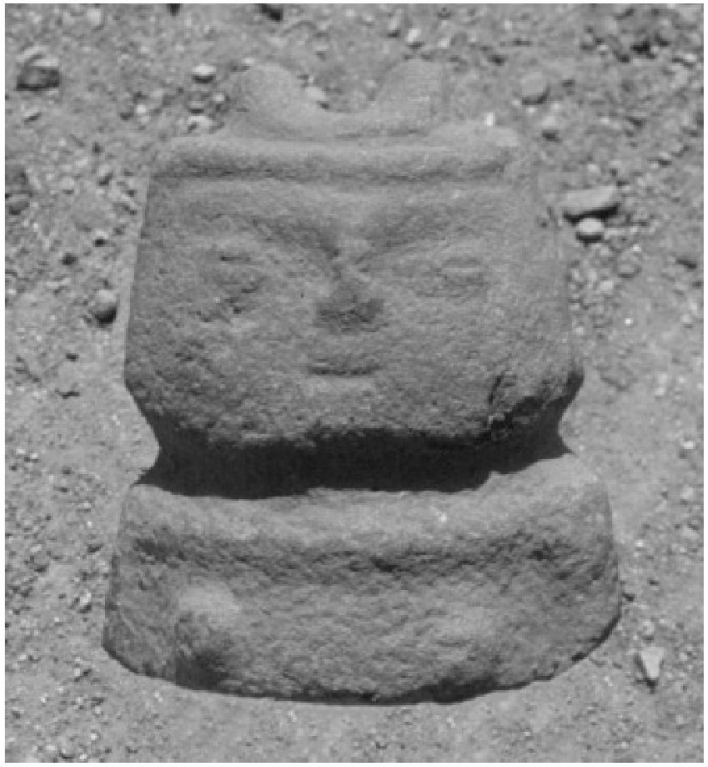

Figure 21. The upper half of an anthropomorphic sculpture from the EI Ranchito (PV-33) site, Jalisco. 


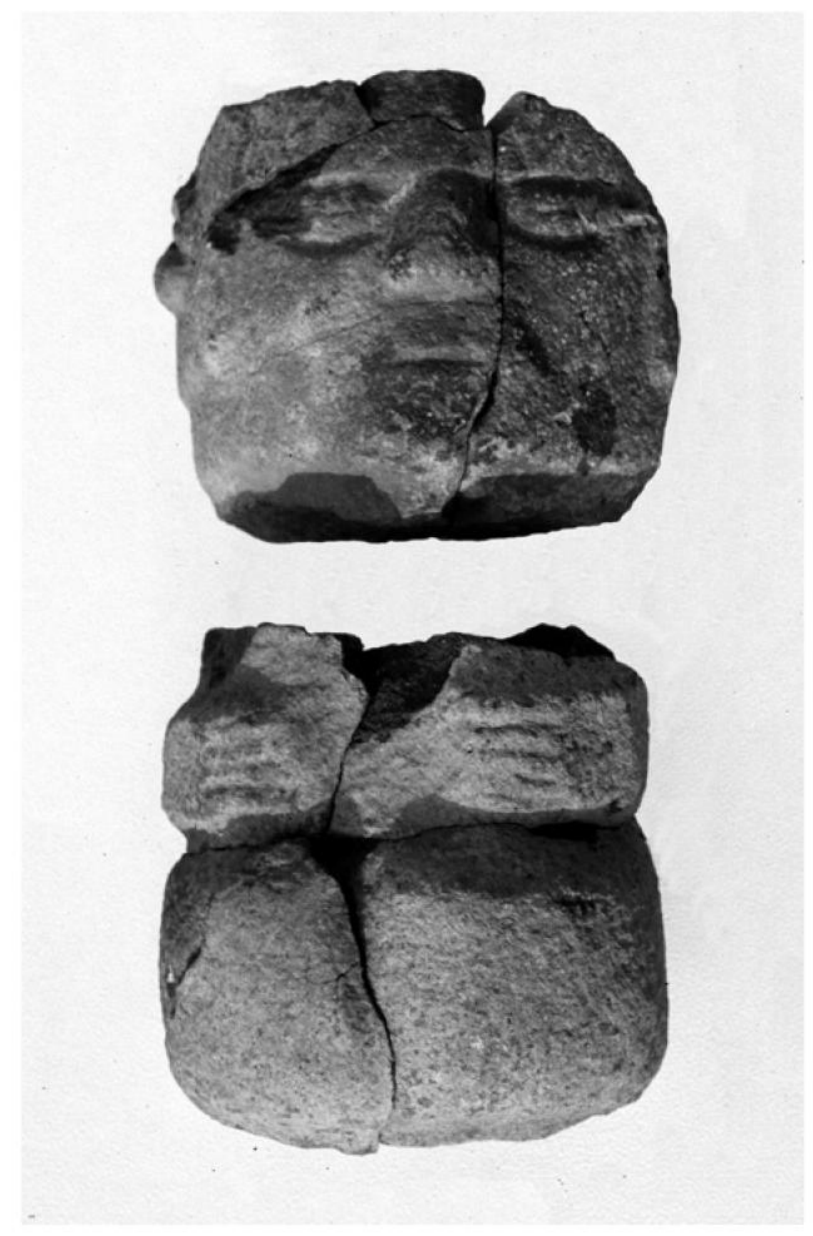

Figure 22. Head and midsection of an anthropomorphic sculpture from the El Ranchito (PV-33), site, Jalisco.

at many other locations, such as, perhaps, at El Ranchito on the other (southern) side of the Banderas Valley.

Because the ethnohistorical data cited herein from Jalisco and Durango generally refer to solitary "idols," it seems likely that the group of sculptures at San Vicente was assembled from a number of different settlements on the northern side of the valley. The internal variation in size and style-and, in two cases, the different type of stone-of the sculptures would seem to support this idea. Certainly, there would have been an ample number of settlements from which the sculptures might have come, for according to Fray Antonio Tello (writing in 1653), when the Spaniards entered the Banderas Valley (in 1525) there were more than 40 principal towns and an estimated 100,000 natives living there (Tello 1968:63)

That the San Vicente "idols" were confiscated by the Spaniards themselves and buried in a pit seems unlikely, judging from the ethnohistorical accounts from western and northwestern Mexico that amply attest to the desire by the Spanish friars to make a great public spectacle of destroying such "idols" to convince the natives of the superior power of the Christianity over that of the devil, who the friars believed resided in or inspired such objects.

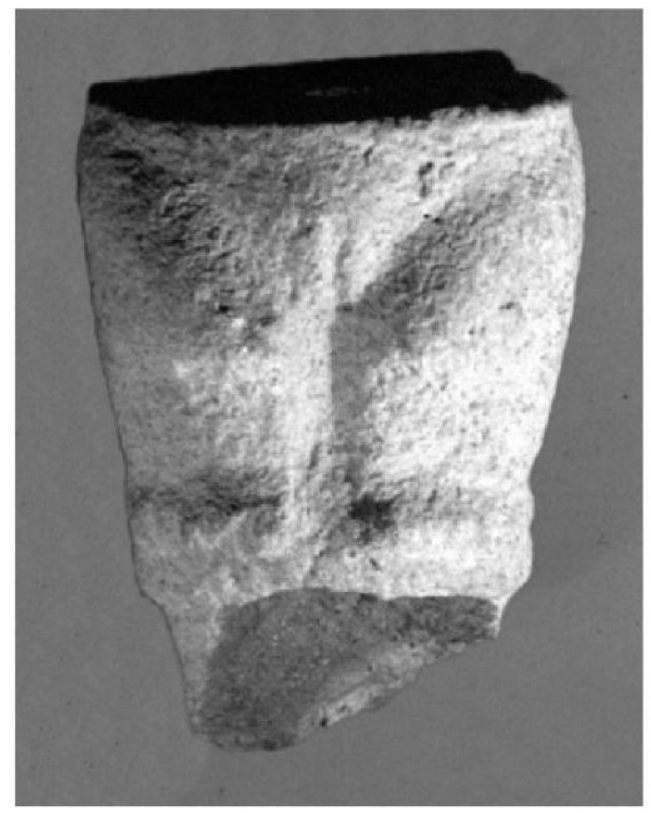

Figure 23. Lower part of an anthropomorphic sculpture from the (PV-33) EI Ranchito site, Jalisco.

\section{DISTANTCULTURALRELATIONSHIPS}

We will close this discussion by pointing out that these anthropomorphic peg-based stone sculptures give additional support for the idea that there was important long-distance coastal contact between western Mexico and Central America during the Postclassic period.

The anthropomorphic peg-based stone sculptures of coastal Jalisco and Nayarit of San Vicente style (of apparently Late Postclassic date) are similar in many ways to some of the stone sculptures of Central America known as "peg-based stone figures" (Stone 1945: Plates 27-28). The Central American peg-based sculptures are found primarily in the Diquís area along the coastal plane of Terraba (the Boruca region) of the Pacific coast in the southwestern part of Costa Rica, as well as inland around Palmar (Graham 1981:catalog nos. 244-245; Mason 1945:Plates 52(d-e), 53(a, c-e), 54(a-d), 55(d-f), 56(b-c, f), 57(a, c), 58(a-f), 59(a, c, e), where they are attributed by Mark Graham (1981:220-221) to Period VI dated A.D. 1000-1550 and proposed to represent warriors. Peg-based stone sculptures have also been found in Honduras (Stone 1945:Plate 28), especially in the southern Pacific coastal area.

The similarities between the San Vicente-style anthropomorphic peg-based stone sculptures of coastal western Mexico and many of the peg-based stone sculptures of Central America include the form of the peg base (sometimes appearing to be phallic), the occasional presence of a ring on which the figure's feet stand, the position of the hands on the stomach, a hermaphroditic aspect (in at least one Central American example), and the occasional depiction of a helmet-like head covering or hair tonsure, as well as a cylindrical or crest-like projection on the top of the head.

For some time, similarities have been pointed out between the decorations on many polychrome pottery vessels found on the Nicoya peninsula of Costa Rica and decorations on roughly con- 
temporary polychrome pottery of the Early Postclassic Aztatlan archaeological culture along the coast of western Mexico (Smith and Heath-Smith 1980). To this may now be added similarities between stone sculptures of both areas, giving added support to the idea of important and intimate Pacific coastal contacts between the two areas during the entire Postclassic period. Such

\section{RESUMEN}

En 1991 una colección de 18 esculturas de piedra fue encontrada accidentalmente en el pueblo de San Vicente, Nayarit, en el lado norte del Valle de Banderas, y eventualmente el grupo de ellas llegó estar depositado en el Museo de Tepic. Una investigación del sitio del hallazgo por Gabriela Zepeda García Moreno no pudo establecer la fecha de las figuras ni determinar la función de ellas. Sin embargo, un estudio posterior del asentamiento prehispánico de San Vicente por José Beltrán indicó que las esculturas probablemente pertenecían al período posclásico. En 2005, estas esculturas fueron inspeccionadas y retratadas en el Museo de Tepic por Joseph Mountjoy, Nathaniel Mountjoy, y Beltrán, y se presentan aquí fotos y una descripción detallada de cada una de ellas que tiene forma antropomorfa. En 1990, Mountjoy había encontrado la mitad inferior de una escultura antropomorfa con base de espiga en la superficie de un sitio al lado sur del Valle de Banderas, y en 1992 y 1993 información adicional sobre tales esculturas fue recuperada en el sitio de El Ranchito en el lado sur del Valle de Banderas, incluyendo fragmentos de esculturas antropomorfas, quebra- coastal relations between the two areas did not begin, however, in the Postclassic. They date back at least to the importation of jadeite ornaments from Guatemala in Middle Formative times (Mountjoy et al. 2004) and may have been an important aspect of western Mexican cultural development during much of the pre-Hispanic period. das, y quemadas, de un pozo cuyo contenido incluía tiestos del posclásico tardío, y carbón que dio una fecha (no calibrada) de 1550 d.C. \pm 60 años. La condición de las esculturas y su contexto sugieren un acto de destrucción de "ídolos" que solía suceder a manos de los frailes españoles a la sazón de la conquista de los nativos. Datos etnohistóricos del siglo XVI en Jalisco y Durango sugieran que estas esculturas de piedra hayan funcionado muchas veces como oráculos para un líder/chaman de la comunidad, o para la comunidad en general. Sin embargo, aspectos iconográficos de las esculturas también sugieran una relación con la fertilidad. El contexto y algunos rasgos distintos de las esculturas de San Vicente sugieran que fueron juntadas por los indígenas y enterradas para protegerlas de la probable destrucción a manos de los españoles. Además, se hace una comparación de las esculturas del Valle de Banderas con esculturas antropomorfas con base de espiga que han sido encontradas en Centroamérica para demostrar otro caso de evidencia apoyando la idea de una relación íntima entre culturas de ambas áreas durante el posclásico.

\section{ACKNOWLEDGMENTS}

The archaeological investigations on which this article is based were supported by the Instituto Nacional de Antropologia e Historia (INAH) Archaeological Council, the INAH Regional Center for Nayarit, the INAH Regional Center for Jalisco, the municipality of Puerto Vallarta, the Uni-

\author{
REFERENCES \\ Acuña, René \\ 1988 Relaciones Geográficas del siglo XVI: Nueva Galicia. Instituto \\ de Investigaciones Antropológicas, Serie Antropológica: 65. Univer- \\ sidad Nacional Autónoma de México, Mexico City. \\ Alcaraz, L. Luis Alberto \\ 1991 Intentaban vender las piezas arqueológicas. Vallarta Opina, \\ no. 4632, 5 June. Puerto Vallarta, Jalisco. \\ Beltrán, José Carlos \\ 1996 Rescate arqueológico de San Vicente Nayarit. Report on file at \\ the INAH Regional Center of Nayarit, Tepic. \\ Graham, Mark M. \\ 1981 Traditions of Costa Rican Stone Sculpture. In Between Continents/ \\ Between Seas: Precolumbian Art of Costa Rica, edited by Suzanne \\ Abel-Vidor, pp. 113-240. H.N. Abrams, New York, and Detroit In- \\ stitute of Arts. \\ Mariano de Torres, Francisco \\ 1965 Crónica de la sancta provincia de Xalisco. Instituto Jalisciense \\ de Antropología e Historia, Guadalajara. \\ Mason, i Alden \\ 1945 Costa Rican Stonework: The Minor C. Keith Collection. Anthro- \\ pological Papers of the American Museum of Natural History, Vol. 39, \\ Part 3. American Museum of Natural History, New York. \\ Mountjoy, Joseph B. \\ 1992 El pasado prehispánico del municipio de Puerto Vallarta. In Una \\ aproximación a Puerto Vallarta, edited by Jaime Olveda, pp. 23-40. \\ El Colegio de Jalisco and the H. Ayuntamiento Constitucional de \\ Puerto Vallarta. \\ 2000 Prehispanic Cultural Development along the Southern Coast of \\ West Mexico. In Greater Mesoamerica, edited by Michael S. Foster \\ and Shirley Gorenstein, pp. 81-106. University of Utah Press, Salt \\ Lake City.
}

versity of Guadalajara, and the University of North Carolina, Greensboro. We are especially grateful for the access to the San Vicente sculptures provided to us by Socorro Varela, director of the Regional Museum of Nayarit in Tepic.

2002 El desarrollo de la cultura indígena en la costa de Jalisco, municipio de Puerto Vallarta. Mexicoa 3(1-2):25-37.

2004 La cultura indígena en la costa de Jalisco, el municipio de Puerto Vallarta. In Introducción a la arqueología del occidente de Méx$i c o$, edited by Beatriz Braniff Cornejo, pp. 339-369. Instituto Nacional de Antropología e Historia, México, D.F., and Universidad de Colima, Colima, Colima.

Mountjoy, Joseph B., James Luhr, Sorena Sorensen, and Nathan Mountjoy

2004 Social and Cultural Implications of Jadetite and Iron Pyrite Jewelry Recovered from the Middle Formative Cemetery at El Pantano, Jalisco, Mexico. Paper presented at the 69th Annual Meeting of the Society for American Archaeology, Montreal.

Pérez de Ribas, Andrés

1944 Triunfos de nuestra santa Fe entre gentes las más bárbaras y fieras del Nuevo Orbe. In Páginas para la Historia de Sinaloa y Sonora, vol. 3, pp. 1-356. Editorial Layac, Mexico City.

Regino, T. Alejandro, and G. Ramírez

1991 Hallan en San Vicente, Nayarit 17 Piezas Arqueológicas. Vallarta Opina, no. 4629, 2 June. Puerto Vallarta, Jalisco.

Smith, Michael E., and Cynthia M. Heath-Smith

1980 Waves of Influence in Postclassic Mesoamerica? A Critique of the Mixteca-Puebla Concept. Anthropology 4:15-50.

Starr, Frederick

1897 Stone Images from Tarascan Territory, Mexico. American Anthropologist 10:45-47.

Stone, Doris

1945 The Basic Cultures of Central America. In Handbook of South American Indians, vol. 4, edited by Julian H. Steward, pp. 169-194. Smithsonian Institution, Bureau of American Ethnology, Bulletin No. 143. Washington, DC. 
Tello, Fray Antonio

1968 Crónica miscelánea de la sancta provincia de Xalisco, libro 77, vol. 1. Instituto Jalisciense de Antropología e Historia, Guadalajara. Williams, Eduardo

1988 The Stone Sculpture ofAncient West Mexico: Analysis and Classification. Ph.D. thesis, University of London, London.

1991 The Stone Sculpture of Ancient West Mexico: Description and Interpretation. Ancient Mesoamerica 2(2):181-192.

1992a Las piedras sagradas: Escultura prehispánica del Occidente de México. El Colegio de Michoacan, Michoacan.

$1992 b$ La escultura de piedra y la religión prehispfnica en el Occidente de Mexico. Barro Nuevo 2(9):3-11. 1992c Sacred Sones: Shamanism and Sculpture in Ancient West Mex ico, In Ancient America: Contributions to New World Archaeology, edited by Nick Saunders. Oxbow Monographs, Oxbow Books, Oxford.

$1998 \mathrm{La}$ escultura prehispfnica del Occidente de México: Nuevos datos Antropología e Historia del Occidente de México, XXIV Mesa Redonda de la Sociedad Mexicana de Antropología, tomo II, pp. 833842.

Zepeda, Gabriela

1991 Esculturas de San Vicente, Bahia de Banaderas, Nayarit. Alica $1^{\mathrm{a}}(2): 16-23$

\section{APPENDIX A. DESCRIPTION OFTHE ANTHROPOMORPHIC SAN VICENTE SCULPTURES}

5. (Figure 4) $74 \mathrm{~cm}$ high. Granite. Male, with a helmet or hairdo having a crest and a tubular projection. The ears have a sunken center and a frontal opening. Small breasts. The hands are united at the waist without depiction of individual fingers. Prominent penis with a scrotum but no depiction of individual testicles. Knees are shown but no depiction of feet; the legs end in a ring below which is a round peg base $8 \mathrm{~cm}$ long. On the back, shoulders, scapulas and buttocks are represented.

6. (Figure 5) $62.5 \mathrm{~cm}$ high. Vesicular basalt. Male, with helmet or hairdo having a cylindrical projection. The ears have a sunken center and two notches in the central part of the frontal area to depict the "tragus." Small breasts. The hands nearly join on the stomach and have five fingers each. The penis and testicles are prominently depicted. The feet have five toes each, and below the feet is a conical peg base $18 \mathrm{~cm}$ long. On the back, the scapulas and buttocks are prominently represented.

7. (Figure 6) $62 \mathrm{~cm}$ high. Vesicular basalt. Male, with a helmet or hairdo having both a crest and a cylindrical projection. The ears have a sunken center and two notches in the central part of the frontal area to depict the "tragus." The central extremities of the clavicles are prominently depicted. Prominent breasts. The hands meet at the center of the stomach and have five fingers each. Each foot has five toes, and below the feet is a conical peg base $6 \mathrm{~cm}$ long. On the back of the head there are two tresses of hair with balls at the lower end. The scapulas, buttocks, and heels are prominently depicted.

8. (Figure 7) $59 \mathrm{~cm}$ high. Vesicular basalt. Male, with a helmet or hairdo having both a crest and a cylindrical projection. The ears are realistically portrayed, down to the small projection of cartilage (the "tragus") in the center of the frontal area. The area of the sternum is sunken. Small breasts. The hands nearly meet at the center of the stomach and have five fingers each. The penis and individual testicles are prominently depicted. The feet have five toes each and are standing on a $4 \mathrm{~cm}$-high ring decorated with a line of nested $\mathrm{V}$-form incisions aligned with the points oriented horizontally to the left. Below the ring is a cylindrical peg base $10 \mathrm{~cm}$ long. On the back, the scapulas, buttocks, and heels are prominently depicted.

9. (Figure 8) $58 \mathrm{~cm}$ high. Vesicular basalt. Male, with a helmet or hairdo having a cylindrical projection. The ears are sunken in the center with the frontal area open. Breasts are quite prominent, although not very large. The hands meet at on the stomach and have four fingers each. The knees are depicted with button-like protuberances. The feet, with four toes each, actually form the peg base, and it is $6 \mathrm{~cm}$ long. On the back, the vertebral column is depicted as a depressed line.

10.(Figure 9) $55.5 \mathrm{~cm}$ high. Vesicular basalt. Male, with a helmet or hairdo having a cylindrical projection. The ears have a sunken center and open frontally with a button-like depiction of the small projection of cartilage (the "tragus") in the center of the opening. Pronounced shoulders and small breasts. Hands nearly meet over the stomach and have five fingers each. Penis and testicles are prominently depicted. The feet have five toes each, and below the feet is a conical peg base $5.2 \mathrm{~cm}$ long. On the back, the scapula and buttocks are prominently depicted.
1. (Figure 10) $55.5 \mathrm{~cm}$ high. Vesicular basalt. Female, with a helmet or hairdo displaying an enormous crest that has a small rectangular projection where it begins on the upper forehead. The ears are sunken in the center and depict the small projection of cartilage (the "tragus") in the frontal central part of the ear. The breasts are large and prominently depicted. The sternum is pronounced, as are the shoulders. The hands meet at the center of the stomach and have four fingers each. The feet have four toes each, and below the feet is a cylindrical peg base $15 \mathrm{~cm}$ long. On the back, the head crest extends down the back to a point a little below the scapulas and at the lower end has a small rectangular projection similar to, yet somewhat larger than, the one on the forehead end. The buttocks are prominently depicted.

2. (Figure 11) $55 \mathrm{~cm}$ high. Vesicular basalt. Male, with a helmet or hairdo displaying a crest that projects slightly over the forehead and extends backward almost down to the center of the figure's back, following somewhat the inward curve of the neck. The ears are sunken in the center and have two frontal notches that outline the small piece of frontally projecting cartilage (the "tragus"). The breasts are prominent, and the area of the sternum is sunken. The hands meet in the center of the stomach and have five fingers on the right hand and four on the left. The penis and testicles are prominently depicted. The knees are represented with button-like projections. The feet rest on a ring. The right foot has five toes, and the left foot has four. Below the ring there is a $15 \mathrm{~cm}$-long cylindrical peg base, slightly damaged, anciently, at the point.

3. (Figure 12) $50.5 \mathrm{~cm}$ high. Vesicular basalt. Male, with a helmet or hairdo having a crest and a cylindrical projection. The central part of the crest is sunken in a $U$ shape, and the crest does not extend down the back of the head. The ears are sunken in the center and open frontally with a button-like depiction of the central projection of cartilage (the "tragus"). The breasts are rather large and prominently depicted, with a depression at the sternum. The shoulders are pronounced. The hands meet on the stomach and have four fingers each. The feet have five toes each and rest on a ring below which extends a $16.5 \mathrm{~cm}$ long cylindrical peg base. On the back, the scapulas and buttocks are prominently depicted, and the vertebral column is represented by a sunken line.

4. (Figure 13) $39.5 \mathrm{~cm}$ high. Vesicular basalt. Female, with a prominent arc-like crest open on the lower part and with five parallel lines extending from front to back on the top part. This crest extends to a point on the back of the figure just below the neck line and looks very much like a large hair tress. There are two raised lines on the head on either side of the crest that also look like hair tresses. The ears have a sunken center and are open frontally, with depiction of the little central projection of cartilage (the "tragus"). The breasts are prominently depicted, as is the sternum. The hands are large and meet over the stomach, virtually covering it. The knees are represented, and the feet have five toes each. There is no peg base below the feet.

11. (Figure 14) $37 \mathrm{~cm}$ high. Granite. Female, with a helmet or hairdo displaying two small crests. The ears have a sunken center and two frontal notches to depict the small central projection of cartilage (the "tragus"). The breasts are not prominently depicted. The hands meet 
over the stomach and have four fingers each. The feet likewise have four toes each, and below them is a cylindrical peg base $9.5 \mathrm{~cm}$ long. On the back of the head there is a tress-like rectangular feature that begins where the two crests end and extends centrally down the back of the head, ending in a small rectangular projection on the lower end. The scapulas are not pronounced, although the buttocks and heels are.

14. (Figure 15) $34 \mathrm{~cm}$ high. Vesicular basalt. Male, with a helmet or hairdo displaying a very slight central depression from front to rear that does not extend down the back of the head. The ears have a sunken center and two frontal notches that depict the small piece of centrally located cartilage (the "tragus"). This figure appears to be smoking a cigar that he holds in his mouth with his right hand. The breasts are small but pronounced. The left hand is resting horizontally on the stomach and has five fingers. No fingers are depicted on the right hand. A penis and scrotum are depicted. The feet have four toes each, and below the feet extends a $2.5 \mathrm{~cm}$-long peg base. On the back of the figure, the scapulas and buttocks are prominently depicted.

15. (Figure 16) $31 \mathrm{~cm}$ high. Granite. Female, with a helmet or hairdo featuring two low-relief crests on the top of the head, front to back, and ending on the back of the top of the head. The ears have a sunken center and an opening to the front without depicting the small central protrusion of cartilage (the "tragus"). There is a somewhat collar-like strap that crosses the upper chest just below the neck and continues back across the shoulders and under the termination of what looks like a rectangular "ponytail" that protrudes off the central upper back right over the strap. The breasts are rather large but not very protruding. The area of the sternum is sunken. The hands do not meet over the stomach. The right hand rests on the stomach, but the left hand is slanted downward just superior to the pubic area. The left wrist has a slight protuberance on the inferior side, and the right wrist has a slight protuberance on the superior side. The right leg is slightly bent at the knee, and the right foot is clearly depicted with five toes. The left leg is recessed as if the figure is shown striding, and the toes are not clearly depicted. Below the feet is an oval (front to back) peg base $3 \mathrm{~cm}$ long. On the back of the figure, the scapulas are not represented, the area being mostly covered by the strap and the "ponytail." The buttocks are large, and the heel of the left foot is prominently displayed.

12. (Figure 17) $26.5 \mathrm{~cm}$ high. Vesicular basalt. Female, with a helmet or hairdo with two low crests on the top of the head, front to back, that in the back extend to the top of the neck, ending rather pointedly. Prominent shoulders. Unlike the "coffee bean" form of the eyes of the other figures, this one has eyes depicted only by slight oval depressions. Cheeks are shown, and the ears are round with a central depression and are open to the front. Shoulders are depicted, and the breasts are large and prominent. The hands rest horizontally on the stomach but are rather separated, and no fingers are shown, nor are toes depicted on the feet. The lower extremity of the figure may be a short peg base $2 \mathrm{~cm}$ long, but is seems more likely that these are the feet, with very large knees depicted just above them. On the back of the figure, the scapulas are not represented, but the vertebral column is represented by a shallow line that runs from the neck down the back, between the large buttocks, between the knees, and between the heels, even under the base of the figure between the feet.

13. (Figure 18) $21 \mathrm{~cm}$ high. Vesicular basalt. Sex not determinable due to the absence of depiction of genitals. Head has a single central lowrelief crest that begins on the forehead, crosses the top of the head from front to back, and extends down the back of the head to the upper line of the neck in "ponytail" fashion. The breasts are pronounced. The hands are positioned horizontally over the stomach, but there is no depiction of fingers. An oval-shaped peg base begins immediately below the hands and extends downward for $7 \mathrm{~cm}$. On the back of the figure, the shoulders and elbows are depicted, and the peg base begins immediately below the elbows. The peg base shows evidence of significant ancient damage on the back in the area of the tip.

16. (Figure 19) $14.5 \mathrm{~cm}$ high. Vesicular basalt. Male with no helmet or hairdo depicted. The face is rather crudely depicted. Shoulders are shown with arms joined in a solid line across the chest without depiction of hands or fingers. From below the arms extends a sort of pegbase-like rectangular body, with large and well-defined penis and testicles at the lower end of the body. There is no representation of legs or feet below the genitals. The line of the shoulders and arms extends across the back of the figure and is the only elaboration of the backside, which is otherwise flat and featureless. 